\title{
Before Lagoa Santa: Micro-remain and technological analysis in a lithic artifact from the Itaparica industry
}

\author{
Rodrigo Angeles Flores ${ }^{1}$, João Carlos Moreno de Sousa ${ }^{2}$, \\ Astolfo Gomes de Mello Araujo ${ }^{1}$, Gregório Ceccantini ${ }^{3}$ \\ 1. Museu de Arqueologia e Etnologia, Universidade de São Paulo. Av. Professor Almeida Prado, 1466 - Cidade \\ Universitária, São Paulo, SP Brazil. \\ Email: Angeles Flores: rodrigo,angelesf@gmail.com; Araujo: astwolfo@usp.com \\ 2. Museu Nacional, Universidade Federal do Rio de Janeiro. Quinta da Boa Vista s/n, Rio de Janeiro, Brazil. \\ Email: jcmorenodesousa@gmail.com \\ 3. Instituto de Biociências, Departamento de Botânica, Universidade de São Paulo. Rua do Matão, 277 São \\ Paulo, SP Brazil. Email: gregorioceccantini@gmail.com
}

\begin{abstract}
:
In this article we present the results of a series of analysis performed on a lithic artifact from the Itaparica industry, a limace, found in Lapa Grande de Taquaraçu, an archaeological site bordering the Lagoa Santa area in Central Brazil. The site was occupied between $11.477 \pm 133 \mathrm{cal}$. BP and 1.087 $\pm 78 \mathrm{cal}$. BP, and the archaeological record for this occupation is related to the archaeological Lagoa Santa Tradition. However, the artifact was found in deeper and relative older archaeological levels, in a different stratigraphy context. The technological analysis confirms its exotic nature, not corresponding to the Lagoa Santa industry, but to another Paleoindian archaeological tradition instead. Its technological features are similar to the limaces related to Itaparica Tradition lithic industries. It's important to notice that this is the only limace found at Lagoa Santa until now, and archaeological context did not allow us to associate it to the Lagoa Santa Tradition. In order to have an insight on the use of this artifact we performed some technological and micro-remain analysis. Various starch grains and other materials were recovered from the active parts of the artifact. The microbotanical analysis indicated the use of the artifact for processing starchy plants. As far as we know, this is the most ancient evidence of the processing of starchy plants in the Americas.
\end{abstract}

Keywords: Brazil; Itaparica industry; Lagoa Santa; lithic technology; Paleoindian; starch analysis

\section{Introduction}

Lagoa Santa is a karstic zone located in central Brazil, $46 \mathrm{~km}$ from Belo Horizonte, capital of Minas Gerais State (Araujo \& Oliveira 2010: 14). Innumerous sinks, dolinas, lapas, caves, grottes and rock shelters are contained within this region. Most of them house archeological sites whose findings have been the subjects of heated academic discussions.

Lagoa Santa was put on the map in the $19^{\text {th }}$ century through the work of the Danish naturalist Peter W. Lund, who explored nearly 200 caves; he was one of the first researchers

Published by the School of History, Classics and Archaeology, University of Edinburgh ISSN: 2055-0472. URL: http://journals.ed.ac.uk/lithicstudies/

This work is licensed under a Creative Commons Attribution 2.5 UK: Scotland License. 
to propose the coexistence between humans and the extinct megafauna. Various researches took place after Lund's, principally to test his findings, but it was only in the middle of the $20^{\text {th }}$ century (in the 1950s) that a proper archaeological excavation was performed by the American-Brazilian Mission (Araujo et al. 2012). This mission was formed by Wesley Hurt, Castro Faria, Paula Couto and Oldemar Blasi; they excavated the Cerca Grande, Lapa das Boleiras and Lapa do Chapéu sites, recovering a great quantity of burials and providing the first absolute date for the region (9700 BP or 11,200 cal. BP from the Cerca Grande site; Araujo, Neves, and Kipnis 2012: 534)

Another international team of archeologists came in the '70s, in the form of the FrenchBrazilian Mission, coordinated by Lamming-Emperaire (Lamming-Emperaire et al. 1975). Apart from the archeological excavations, the team included ethnographic and geological studies. The systematic register of cave paintings was the first of its kind in Brazil (Prous, Fogaça, \& Ribeiro 1998: 6). However it was their excavations at Lapa Vermelha IV that brought an important discovery: The skull of Luzia, made famous decades later by the craneomorfological studies of Walter Neves and colleagues in which they proposed an affinity for the Paleoindians within the Lagoa Santa Region with modern Austromelanesian populations rather than Asian, which were confirmed by subsequent studies (Neves \& Pucciarelli 1991; Bernardo 2007: 239-240; Neves \& Hubbe 2005; Neves, et al. 2007; Neves et al. 2004; Neves et al. 2003). Nevertheless, not all researchers agree and Seguchi and colleagues (2011) see an affinity with the Jomon population.

More recently, since the year 2001, the Laboratory of Human Evolutive Studies of the University of São Paulo (LEEH-USP) worked on the region throughout the archaeological project: Origens e Microevolução do Homem na América: Uma Abordagem Paleoantropológica (FAPESP 99/00670 -7 e 04/01321-6). This interdisciplinary project continued with the excavations of past projects (Cerca Grande IV, Lapa das Boleiras, Lapa do Santo), as well as new sites (Lapa Grande de Taquaraçu), including open-air sites (Sumidouro and Coquerinho). Various ground-breaking archaeological finds have been produced from this project, including the oldest figurative petroglyph ever found in the New World (Neves et al. 2012). In sum, we now know the following about the Lagoa Santa region (for a more detailed study of the most recent findings in Lagoa Santa region, we recommend reading Araujo et al, 2012):

1. The region's first occupations were after $12,500 \mathrm{cal}$. BP;

2. The skeletal remains from this time differ from modern native groups;

3. There is no evidence that the Lagoa Santa people were hunting megafauna even though they were contemporary;

4. The Lagoa Santa lithic industry is different from other Brazilian contemporary groups; and

5. The subsistence of the inhabitants was based on collecting tubers, fruits and seeds, complemented with fishing and hunting of small prey.

More on the topic number 4 in the following paragraphs.

\subsection{Paleoindian lithic industries in Brazil}

Broadly speaking, three industries were identified at the Pleistocene-Holocene transition in the territory now known as Brazil (Figure 1):

a. The Umbu industry: Found in southern Brazil, from the central part of São Paulo State and extending to Argentina, Paraguay and Uruguay. This industry is characterized by the large presence of bifacial projectile points of diverse types with little form variability in time (Araujo \& Pugliese 2009; 2010), but some variability in space 
(Okumura \& Araujo 2013; 2014). The most ancient occupations related to this industry date from 11,555 BP (13,459 cal. BP) (Miller 1987).

b. The Itaparica industry: Established in central and northwestern Brazil. Characterised by the presence of extensively reduced and retouched artifacts and dominance of unifacial artifacts, known colloquially as 'limaces'. Assemblages related to this industry practically has neither bifacial artifacts nor cores (Araujo \& Pugliese 2009). Itaparica industry is based on a large production of limaces by core-flaking of thick blades and unifacial reduction and retouch (Calderón 1973; Schmitz et al. 1989, Fogaça 2003; Lourdeau 2010; Moreno de Sousa 2016). Typical Itaparica limaces tend to have more than one functional edge, and its technological features are usually related to scrapping activity (Lourdeau 2010; Moreno de Sousa 2016). The most ancient occupations related to this industry date from 12,070 (14,122 cal. BP) (Prous 1997).

c. The Lagoa Santa Lithic industry distinguishes itself from the above mentioned by the lack of formal artifacts, specially limaces and bifacial points. Instead, this industry is dominated by little sized flakes, some of them retouched. The raw material most used by the manufacturers of this industry was quartz, however, there is an apparent preference for the flint in the earliest levels of some sites, such as Lapa das Boleiras (Araujo \& Pugliese 2010) and Lapa do Santo (Moreno de Sousa 2014: 17). This industry does not seem to experience significant changes from 12,500 to 8,000 cal. BP. The Lagoa Santa lithic industry could be described as "a microlithic industry based small flakes of crystal quartz and flint, with casual grounding techniques on other kinds of raw material” (Moreno de Sousa 2014: 169).

Formal, standardized artifacs are very rare in the Lagoa Santa Region, at least in the Pleistocene - Holocene transition, and only 19 bifacial points have been reported in all the years that the region has been investigated (Araujo \& Pugliese 2010: 80). It is even more uncommon to find a unifacially reduced artifact in the area and only two have been recovered so far: One outside the Cerca Grande VI site, found without stratigraphical context (Araujo, et al. 2012: 538), and another one recovered during the excavations at Lapa Grande de Taquaraçu, which is the focus of this article.

\subsection{Archaeobotanical studies in Lagoa Santa}

Although not a very common practice, archaeological projects in the region have included a description of the botanical remains found during their excavations (e.g., Hurt \& Blasi 1969; Resende \& Prous 1991). However, it is only until recently that studies with archaeobotanic objectives have taken place, most of them focusing on macroremains (Rodrigues Silva 2006: 11; Melo Junior \& Ceccantini 2010; Nakamura, et al. 2010). Microremain studies are, however, still not applied in the area, the master's thesis of Gardiman (2014: 8) being the only study so far that focuses on starch grains, though with a more recent temporality than the material analyzed in this article.

\subsection{Taquaraçu archaeological site}

The archaeological site Lapa Grande de Taquaraçu is a limestone rockshelter (approximately $30 \times 9 \mathrm{~m}$ in extension) located next to the Taquaraçu river about $20 \mathrm{~km}$ to the west of the APA of Lagoa Santa (Environmental Protection Area) (Figures 2 and 3).

The site was excavated between the years 2003 and 2008 as part of the project "A Lapa Grande de Taquaraçu: Análise Geoarqueológica de um Sítio Abrigado do Período Paleoíndio no Sudeste Brasileiro", as part of the above mentioned project "Origens e Microevolução do Homem na América: Uma Abordagem Paleoantropológica”. 


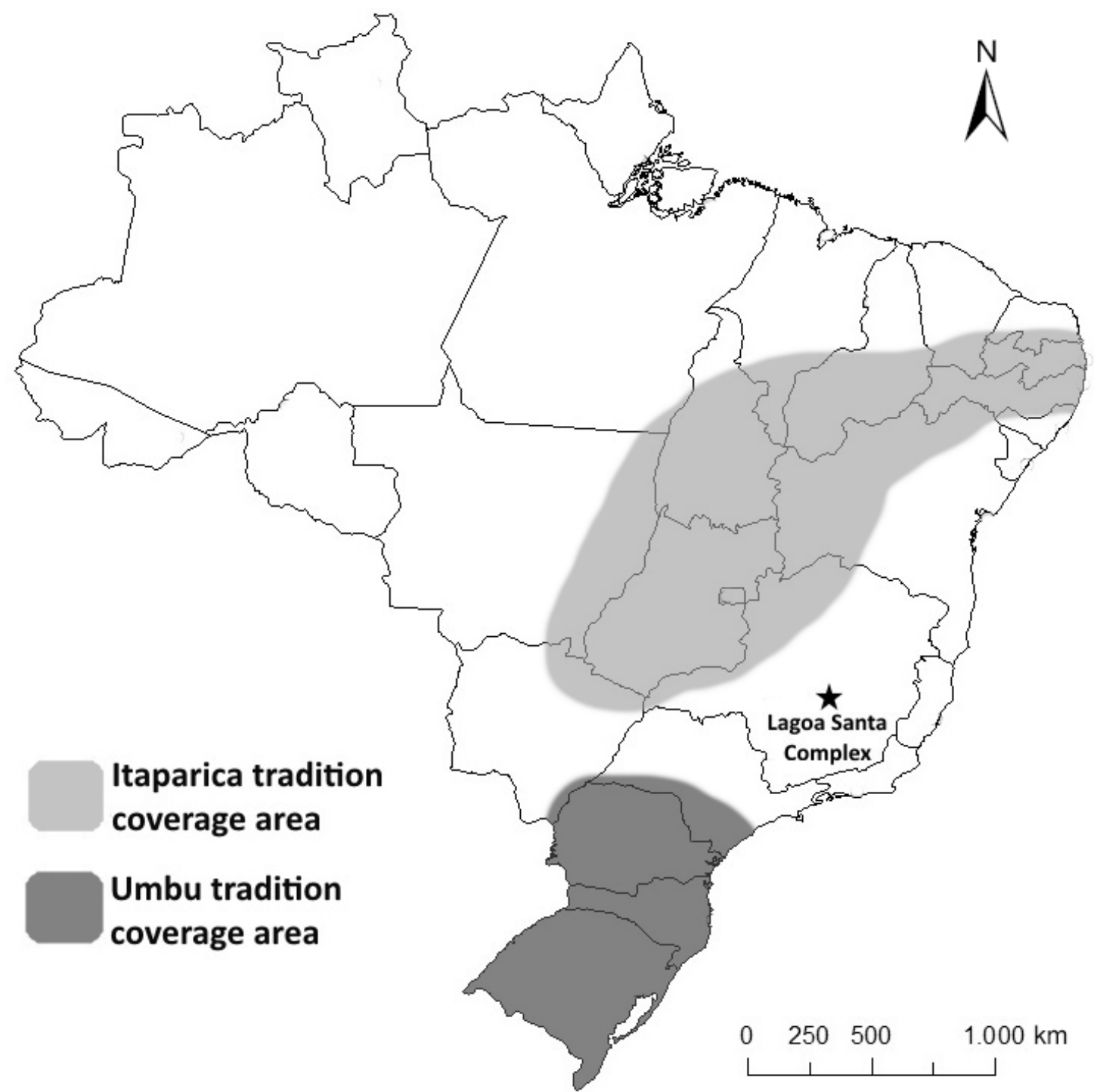

Figure 1. Lagoa Santa archaeological sites complex location and assumed coverage areas of Itaparica and Umbu traditions.

During the excavations an $80 \mathrm{~cm}$ thick archeological layer was defined. This layer is composed mainly of well stratified, anthropogenic sediments (mainly wood ash; Figure 4), with a small geogenic contribution (Tudela 2013: 77), containing a large quantity of lithic, plant and animal remains, including two human skeletons. Ceramic pieces were also found, but in small quantity and only at the surface. The lithic material is mainly composed of hyaline quartz flakes and splinters, with some flint occurring in the lower levels, showing the typical characteristics of the Lagoa Santa industry.

The samples recovered for dating indicated an occupation between 11,477 $\pm 133 \mathrm{cal}$. BP and 1,087 $\pm 78 \mathrm{cal}$. BP, with a hiatus between 9,028 \pm 82 and 1,087 $\pm 78 \mathrm{cal}$. BP (Table 1). This hiatus is marked by the complete absence of anthropogenic sediment accumulation, a process already observed at other sites in the Lagoa Santa area (Araujo et al. 2005; Araujo et al. 2008; Araujo et al. 2012).

During the excavation of one of the units (H8), a plain-convex artifact was found between the large limestone boulders at the bottom of the unit $(90 \mathrm{~cm}$ deep, see Figures 3,4 and 5). It was immediately stored inside a clean plastic bag, and not subject to any cleaning or washing before this study. The artifact was clearly an isolate find, not related to any of the other cultural materials present in the upper layers, and without associated charcoal. 
Therefore, we can only say that its deposition precedes the oldest age obtained for the main site occupation (i.e. older than 11,500 cal. BP). This is the artifact that we focus on this article.

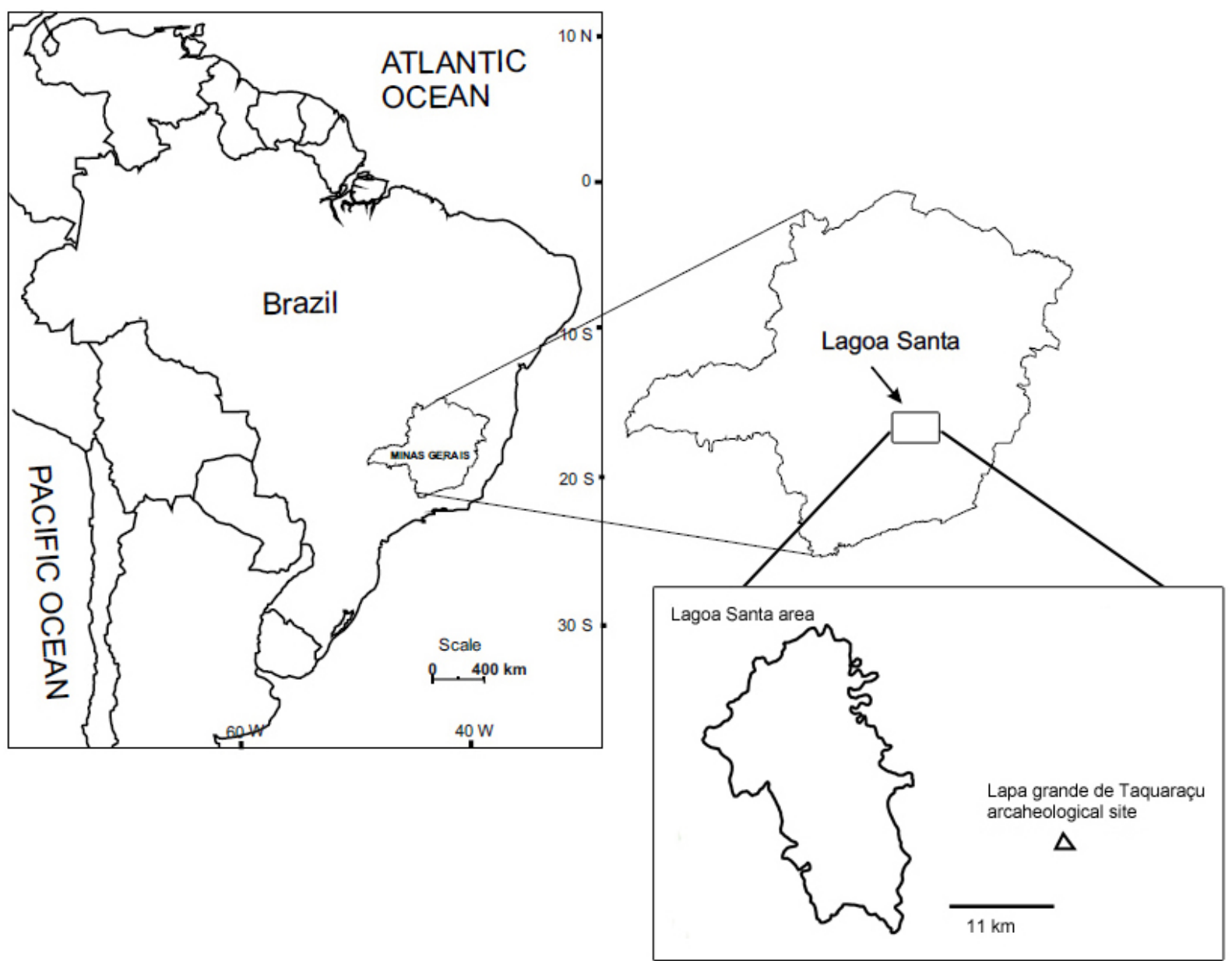

Figure 2. Localization of the Lagoa Santa area and the Lapa Grande de Taquaraçu archaeological site. Modified from Araujo, Neves and Kipnis (2012).

Table 1. Calibrated dates from the Lapa Grande de Taquaraçu using the calibration curve CalPal2007_HULU (Danzeglocke et al. 2007)

\begin{tabular}{lcccc}
\hline Sample number & Level & Facies & $\begin{array}{c}\text { Radiocarbon date } \\
\text { (Years BP) }\end{array}$ & $\begin{array}{c}\text { Calibrated date } \\
\text { (Years BP) }\end{array}$ \\
\hline TQ 421 & 1 & 2 & $1160 \pm 60$ & $1087 \pm 78$ \\
TQ 417 & 1 & 3 & $8080 \pm 40$ & $9028 \pm 41$ \\
TQ 402 & E Profile & $\mathrm{X}$ & $8230 \pm 50$ & $9202 \pm 82$ \\
TQ 430 & 3 & 9 & $8310 \pm 40$ & $9344 \pm 59$ \\
TQ 441 & 4 & 11 & $8730 \pm 40$ & $9703 \pm 82$ \\
TQ 404 & E Profile & $\mathrm{X}$ & $8730 \pm 50$ & $9720 \pm 102$ \\
TQ 454 & 5 & 11 & $8910 \pm 40$ & $10052 \pm 96$ \\
TQ 459 & 6 & $\mathrm{X}$ & $9040 \pm 40$ & $10218 \pm 17$ \\
TQ 297 & 7 & $\mathrm{X}$ & $9540 \pm 90$ & $10896 \pm 164$ \\
TQ268 & 8 & $\mathrm{X}$ & $9550 \pm 60$ & $10911 \pm 139$ \\
TQ295 & 6 & $\mathrm{X}$ & $9620 \pm 40$ & $10979 \pm 131$ \\
TQ 536 & 9 & 19 & $9990 \pm 60$ & $11477 \pm 133$ \\
TQ 544 & 10 & 20 & $9900 \pm 60$ & $11349 \pm 89$ \\
\hline
\end{tabular}




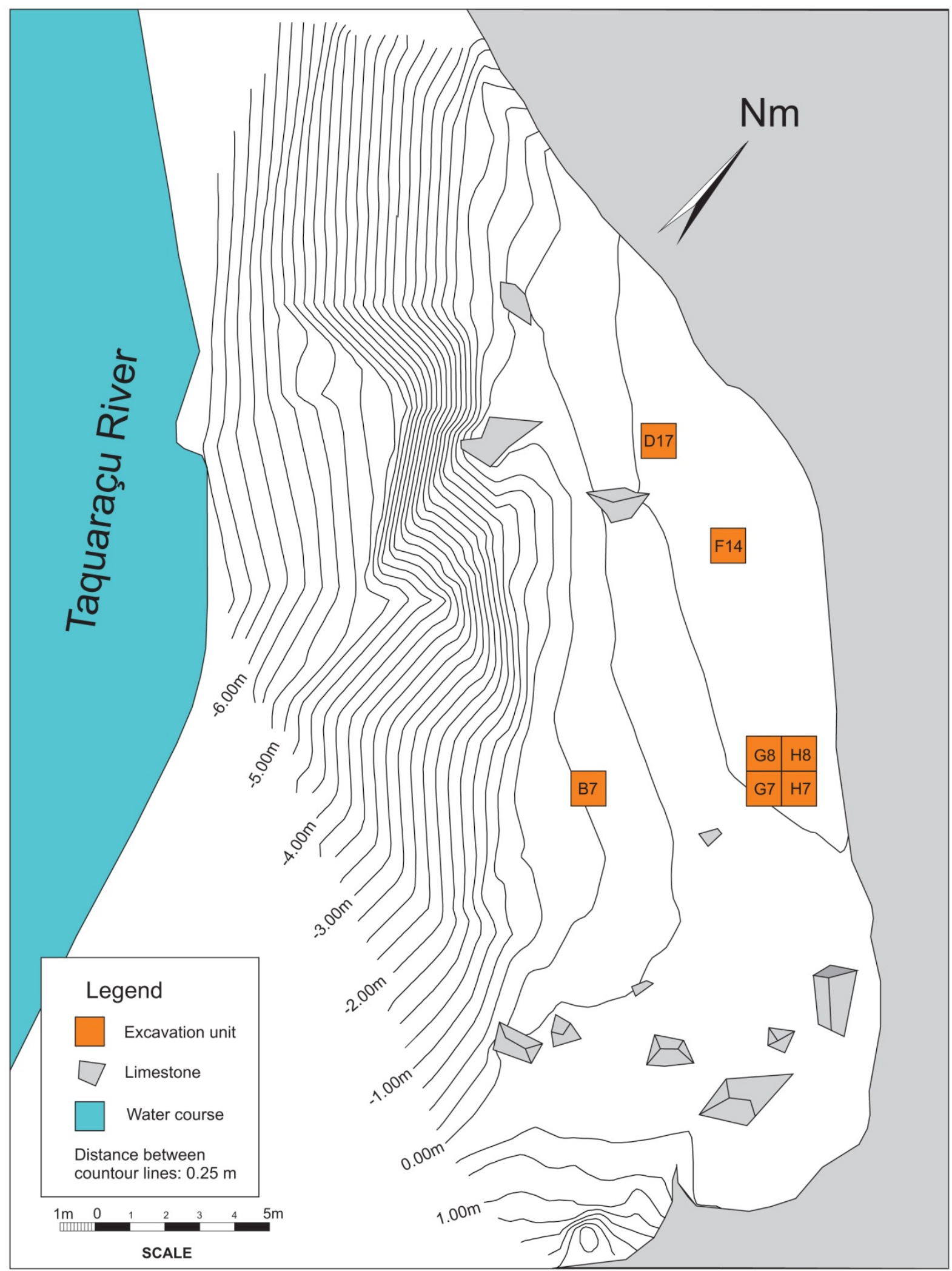

Figure 3. Topographic map showing the location of the excavation units at Lapa Grande de Taquaraçu Rockshelter, including $\mathrm{H} 8$ where the artifact was recovered. Abbreviations - Nm - magnetic north. Diagram by Astolfo Araujo, 2015. 


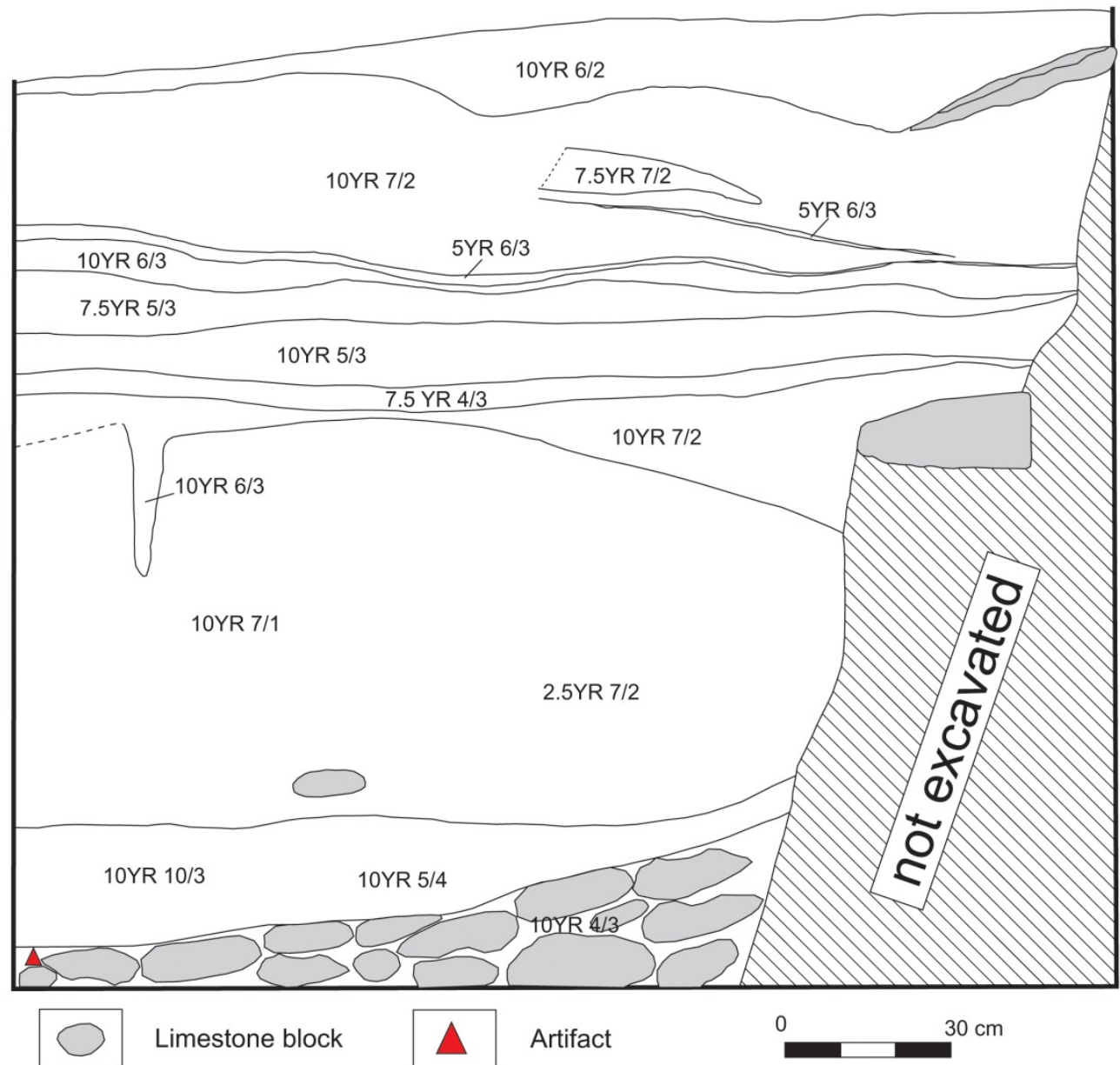

Figure 4. Lapa Grande de Taquaraçu, Unit H8 - north profile image, showing a thick anthropogenic sediment accumulation over the basal layer of limestone pebbles and cobbles where the artifact was recovered. The location of the artifact is indicated by a triangle. Drawing by Astolfo Araujo.

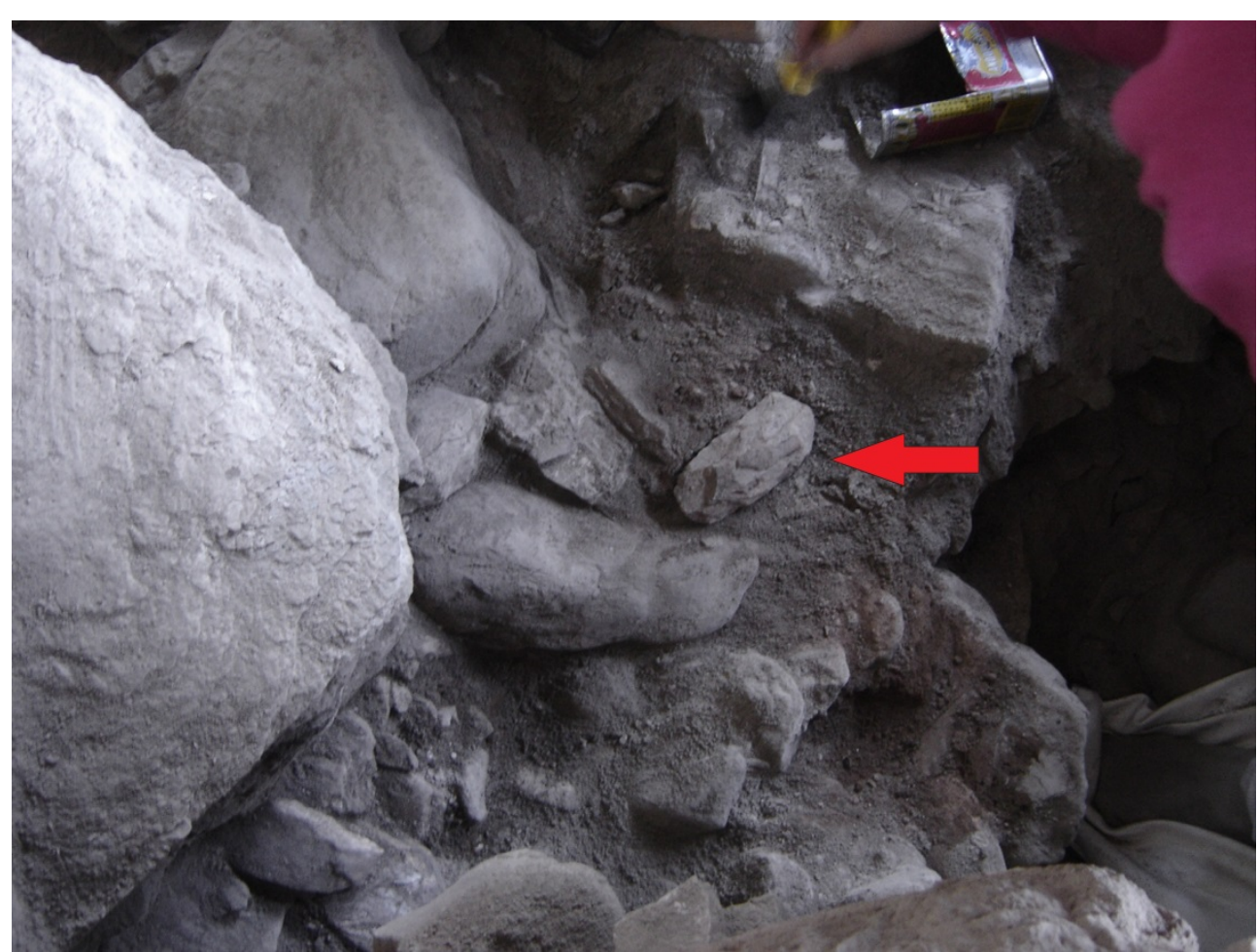

Figure 5. Location of the artifact. Photo by Astolfo Araujo. 


\section{Methods}

The artifact was the object of various analyses with the aim of understanding its manufacturing process and its use, some of which we describe below.

\subsection{Micro-remains analysis}

In order to recover the starch grains from this artifact, we created a protocol based on the ones described by Cascon (2009: 47-56; 2010: 96-103), Pagán Jiménez amd Oliver (2008), and Pagán Jiménez (2011). Most of the analyses were performed at the Laboratory of Plant Anatomy of the Institute of Biosciences of the University of São Paulo, Brazil; additional equipment, such as the ultrasonic bath and a centrifuge was provided by the Laboratories of Cellular Biology and Plant Physiology respectively.

With the aim of looking for concentrations of biological material, the artifact was placed under a Nikon Eclipse E200 microscope equipped with dark field and examined at low magnifications (4x, 10x with a 10x ocular). After this survey, the sediment on the artifact was brushed off with a bright new disposable toothbrush; this brushing was made separately in different parts of the artifact: proximal, left side, right side and distal (Figure 6). The differential selection of the tool into parts was made by identifying three active areas in the artifact, and one handling area. A different toothbrush was used for every individual section of the artifact, and the sediment was stored in a clean new Falcom flask. The operation was repeated with a toothbrush soaked in distilled water. In this way, the limace was apparently cleaned of all sediment, but a little bit of it was in the microcracks; in order to recuperate that sediment (under the supposition that this would be the most related to the use of the artifact) the different parts of the artifacts were individually put in an ultrasonic bath for 10 minutes, the resulting pellet was then stored in a clean new Falcom Flask. This process resulted in two different sediments for each individual part of the artifact: One resulted from the dry brushing (sediment I), and another sediment from the ultrasonic bath (sediment II).

For the recovery and separation of the starch grains from the sediments, each sample was mixed with a Cesium Chloride $(\mathrm{CsCl})$ solution with a $1.8 \mathrm{~g} / \mathrm{cm}^{3}$ specific gravity, stirred for 30 seconds and then centrifuged at 2,500 rpm for 12 to 15 minutes. By doing this, the starch grains with a specific gravity less than $1.8 \mathrm{~g} / \mathrm{cm}^{3}$ stay in the supernatant (A). Even so, the resulting sediment (B) was analyzed because it could contain starch grains with a specific gravity greater than $1.8 \mathrm{~g} / \mathrm{cm}^{3}$. After this, A and B were poured into an $2 \mathrm{~mL}$ eppendorf flask adding 0.5 or $1 \mathrm{~mL}$ of distilled water, shaken for $10-15$ seconds, so as to eliminate all the $\mathrm{CsCl}$ crystals that could be formed, and then placed back into the centrifuge for 20-25 minutes at 3,200 rpm. The centrifugation was repeated 2 more times with less water each time. After this step, one drop of the resulting solution was poured on to a slide, covered with a sterile petri dish, and then a drop of glycerol was added. It was just after this procedure that a coverslip was placed on top and sealed with nail polish.

The slides were analysed under a Leica DMLB microscope with polarized filters. Each starch and other biological material encountered was photographed with a Leica DFC310FX camera, described and measured with Image J free software (Rasband 1997).

In order to minimize the contamination by modern starch, the plastic and glass materials used were immersed in a Dimethyl Sulfoxide (DMSO) solution for 8 hours and then washed with distilled water. The DMSO is a standard solvent used in plant storage laboratories for the elimination of starch. The area of work was cleaned daily with alcohol (ETOH) and only non-powdered plastic gloves were used. Following the recommendations of past researches (Laurence et al. 2011; Crowther et al. 2014) for detecting some possible airborne starch present at the air, petri dishes were filled with distilled water and left in different laboratory 
areas that were used for the starch analysis for 12 days. In addition, the occupied solutions were routinely analysed for the presence of starch.

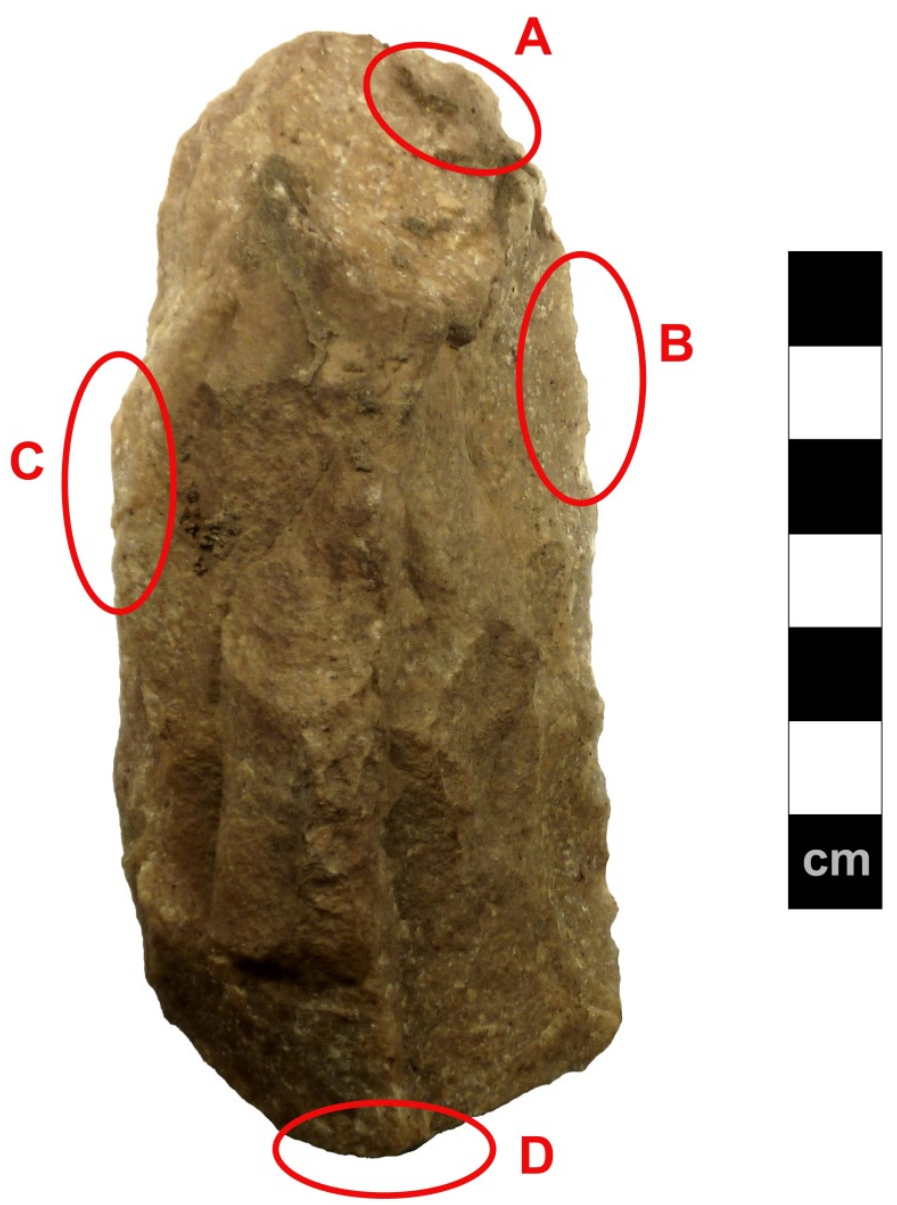

Figure 6 Unifacially reduced artifact found at Lapa de Taquaraçu archaeological site, with the signalized areas where sediment was recovered for starch. A: distal area; B: right area; C: left area; D: proximal area. Photo by João Carlos Moreno da Sousa.

\subsection{Additional testing}

In addition to these studies, we did a preliminary test to detect the presence of hemoglobin in the same parts that were analysed for the presence of starch. We used the urinalysis test strip technique described by Malainey (2011) applied successfully in archaeological contexts by Matheson, Hall and Viel (2009) and Williamson (2000). Results are presented elsewhere (Angeles Flores 2015).

\subsection{Technological analysis}

The applied method of analysis was based on the operatory chain notion of Mauss (1936) and Leroi-Gourhan (1965), as well as the notions of lithic technological features of Inizan et al (1995), the notion of Technofunctional Unities (UTFs) of Boëda (1997: 107-108) and the basic procedures of technical drawing of Dauvois (1976). In this sense, the technological features were useful for different stages of production (debitage, reduction and retouch) identification, as well for the understanding of the diachronic organization of the negatives. The transformative UTFs (i.e. active edges) were also identified based on technological features patterns. 


\section{Results}

\subsection{Technology}

The artifact presents a typical Itaparica industry limace set of features: It is a large and thick flake with unifacial reduction and unifacial retouch (Figure 7). The main features are presented in Table 2.
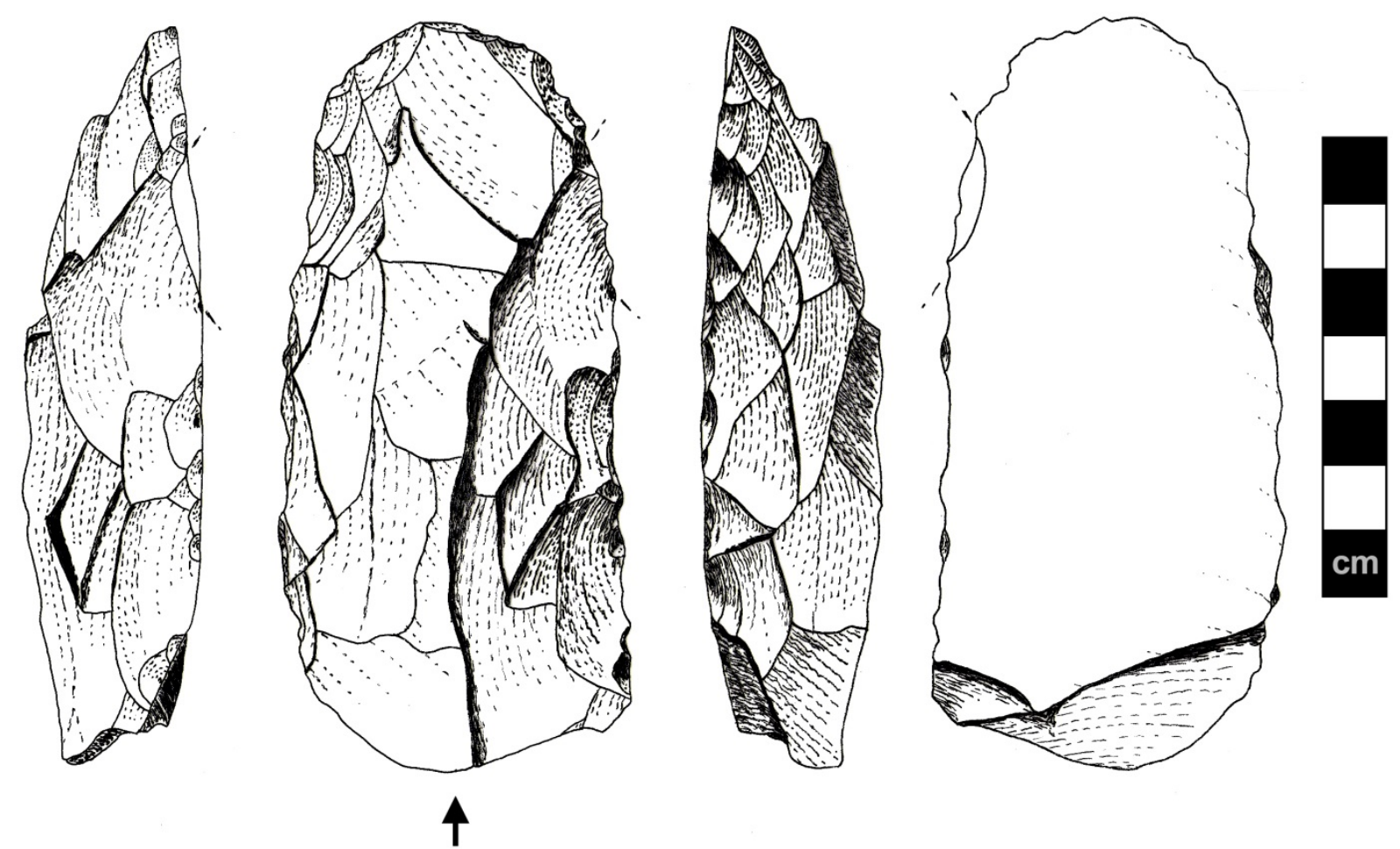

Figure 7. Limace found at Lapa de Taquaraçu archaeological site, Dark arrow represents the absence of platform and bulb in the blank flake. Scale bar is $7 \mathrm{~cm}$. Drawing by João Carlos Moreno da Sousa.

Table 2. Artifact main features.

\begin{tabular}{ll}
\hline Blank & Large and thick flake \\
\hline Raw material & Quartzite \\
Weight & $190.9 \mathrm{~g}$ \\
Length & $114 \mathrm{~mm}$ \\
Width & $56 \mathrm{~mm}$ \\
Thickness & $28 \mathrm{~mm}$ \\
Number of transformative UTFs & 3 \\
\hline
\end{tabular}

Four debitage negatives still remain in the superior artifact face. Those negatives are not enough to understand the core features, and the technological organization of debitage flaking in the first production stage. In the second stage the blank flake was produced.

The third stage was the proximal and distal areas reduction (Figure 8). Proximal reduction aimed to remove the platform and the bulb in order to leave a totally flat inferior face, and possibly prepare a handle area. Distal reduction aimed to prepare a transformative UTF (Figure 9).

The fourth stage was the left and right sides reduction sequences, in order to prepare two opposite transformative UTFs. The fifth stage was the retouch of the three transformative UTFs (Figures 8 and 9). All of the identified transformative UTFs present features indicate their use as scrapers. 


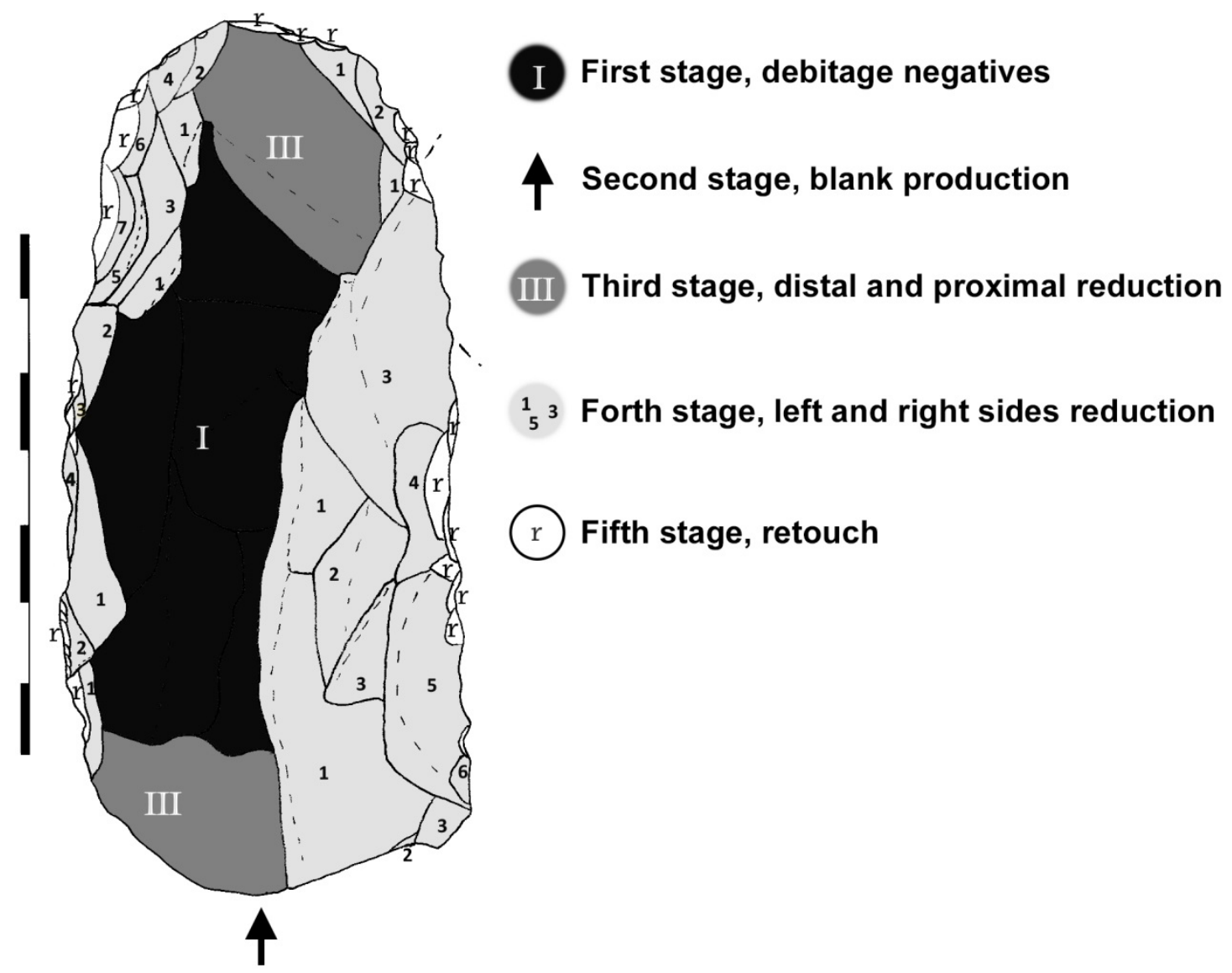

Figure 8. Diachronic organization of artifact negatives. Limace found at Lapa de Taquaraçu archaeological site. Scale bar correspond to $7 \mathrm{~cm}$. Schematic drawing by João Carlos Moreno da Sousa.

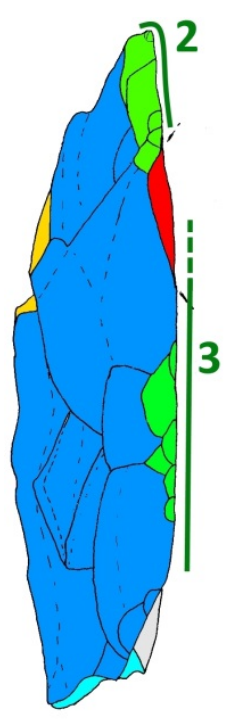

Broken

\section{Reduction} (handle area)

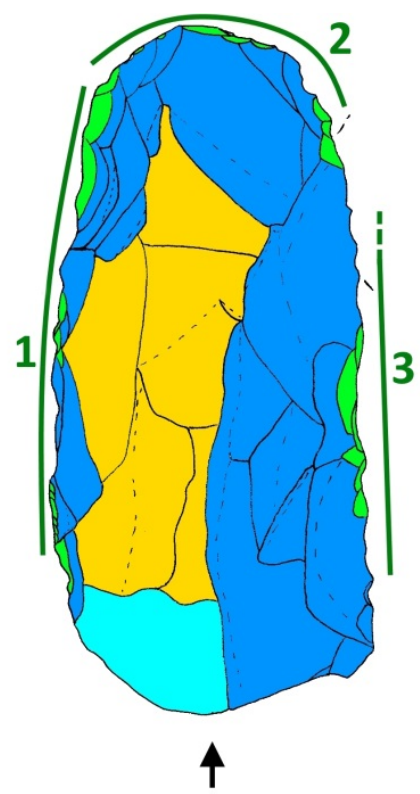

Positive Area

Reduction (active area)
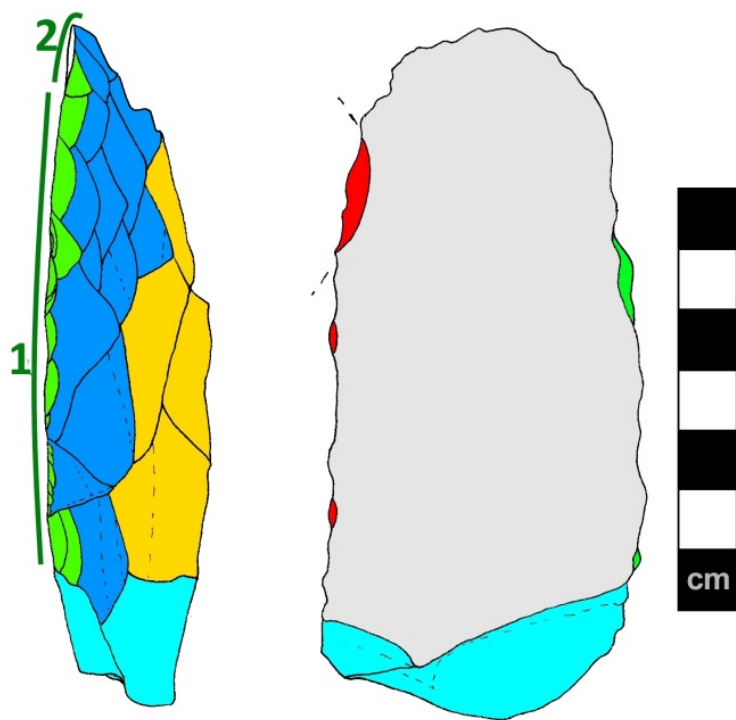

Debitage

\section{Retouch}

Figure 9. Artifact production stages and transformative UTFs locations. Limace found at Lapa de Taquaraçu archaeological site. Sclae bar has $7 \mathrm{~cm}$. Scheme drawing by João Carlos Moreno da Sousa. 
Some broken areas were identified, but they do not present any difference in patina, which means they had probably broken before the artifact was discarded.

The transformative UTFs main features are presented in Table 3. It is not possible to identify features patterns on negatives, obviously because this is the only piece found. However, this piece presents reduction negatives that vary between $1 \sim 3 \mathrm{~mm}$ length and 2 7 mm width, with flat surfaces, and some reflected accidents.

Table 3. Artifact transformative UTFs main features.

\begin{tabular}{llll}
\hline & UTF 1 & UTF 2 & UTF 3 \\
\hline Location & Left border & Distal border & Right border \\
Reduction area angle & $65^{\circ}$ & $30^{\circ}$ & $50^{\circ}$ \\
Reduction area surface & Plan & Plan & Plan \\
Retouch edge area angle & $70^{\circ}$ & $65^{\circ}$ & $50^{\circ}$ \\
Retouch edge area surface & Plan & Plan & Plan \\
Edge contour & Irregular & Convex denticulate & Rectilinear denticulate \\
& denticulate & & \\
Edge length & $90 \mathrm{~mm}$ & $43 \mathrm{~mm}$ & $>60 \mathrm{~mm}$ (broken) \\
\hline
\end{tabular}

\subsection{Micro-remains}

Starch grains were recovered from the distal, left and right areas of the artifact, but not in the proximal area. These grains were found in the sediment I as well as in sediment II, except for the left part, where starch grains were found only in sediment II. Modified starch grains were found in the sediment I as well as in the sediment II (Figure 10). The number of starch grains found in each part of the tool is 10 or less, the right side appearing to be an exception, with almost 40 grains. The latter is an overrepresentation due to a concentration of more than 200 starch grains (Figure 11 S), of which 35 were counted and presented in the graph.

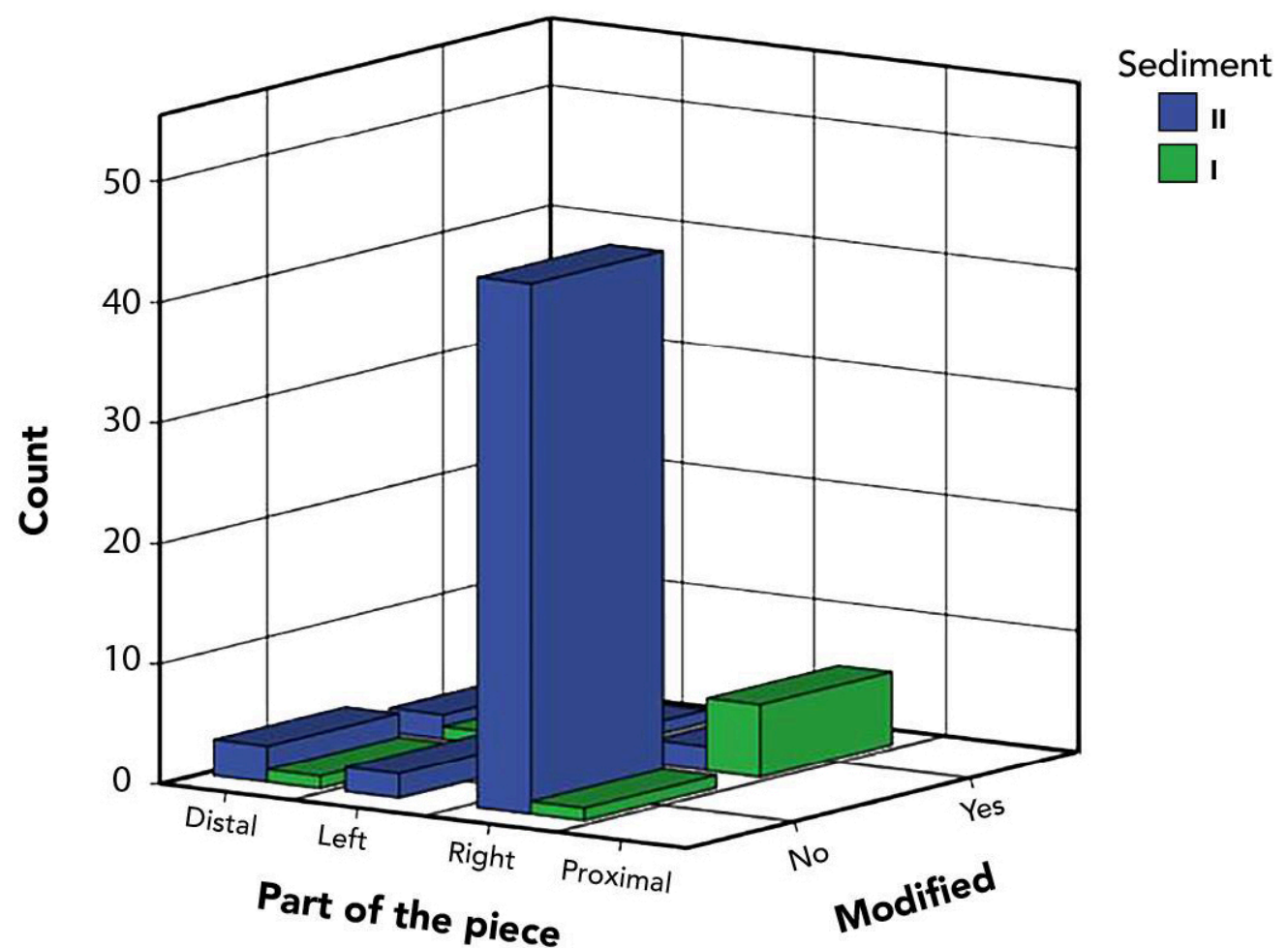

Figure10. Number of starch grains (modified or non-modified) found in the different parts of the artifact. 

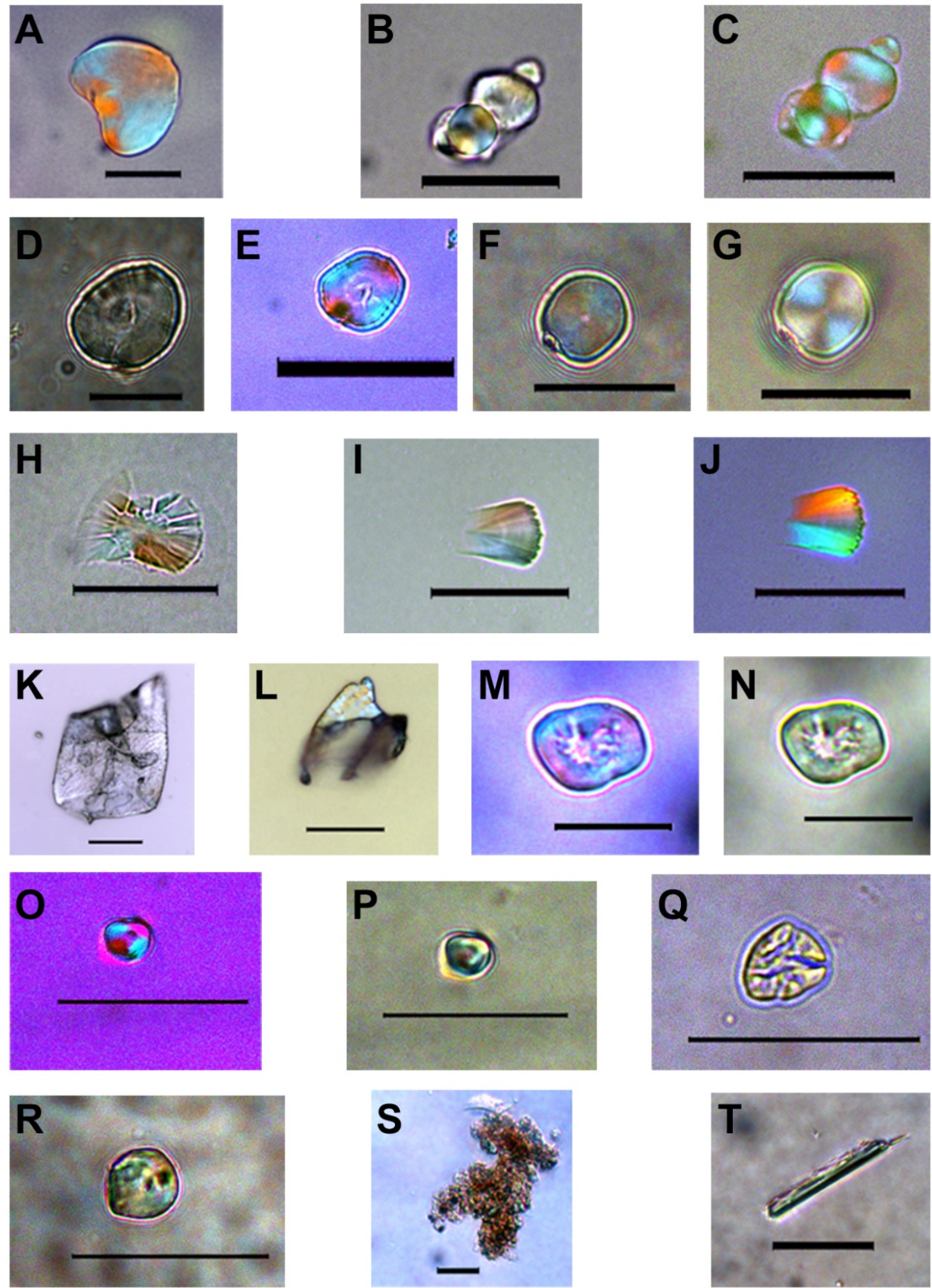

Figure 11. Starch grains and various elements recovered from the sediment I (A-L) and sediment II (M-T) at the right side of the artifact. A-G, M-S: Starch grains. A: Starch grain 1 from sediment I; Starch grains 2-6 from sediment I; D-E: Grain 7 for sediment I; F-G: Grain 8 from sediment I; M-N: Starch 1 from sediment II; O-P: Starch grain 2 from sediment II; Q: Starch grain 3 from sediment II; R: Starch grain 4 from sediment II; S: Starch grains 5-200 from sediment II (35 of them counted and measured for this article). H-J: Non-identified elements; H: Non-identified element 1 from sediment I; I-J: Non-identified element 2 for sediment I. K-L: Vessel elements; K: Vessel element 1 for sediment I; L: Vessel element 2 for sediment 1. T: Possible trichome. Photos taken under bright field (B, D, F, H, I, K, L. N, P, Q, R, S, T) and polarized (A, C, E, G, J, M, O) light. Scale Bar: A-J, M-N, S: $20 \mu \mathrm{m}$; O-R, T: $50 \mu \mathrm{m}$; K-L: $100 \mu \mathrm{m}$. Photos by Rodrigo Angeles Flores. 
Beside the starch grains, other elements were recovered from the sediments I and II all over the archaeological piece, including the proximal side, where no starch grains were found (Figure 12). Some of these elements were not identified, and some of them tentatively identified, such as some possible phytoliths (Figure 13 B-C,) and a possible trichome (Figure $14 \mathrm{~T}$ ). Amongst the identified elements, raphides (Figure $14 \mathrm{C}-\mathrm{F}$ ) and vessel elements (Figures 15 O-P and 16 D-E) were found.

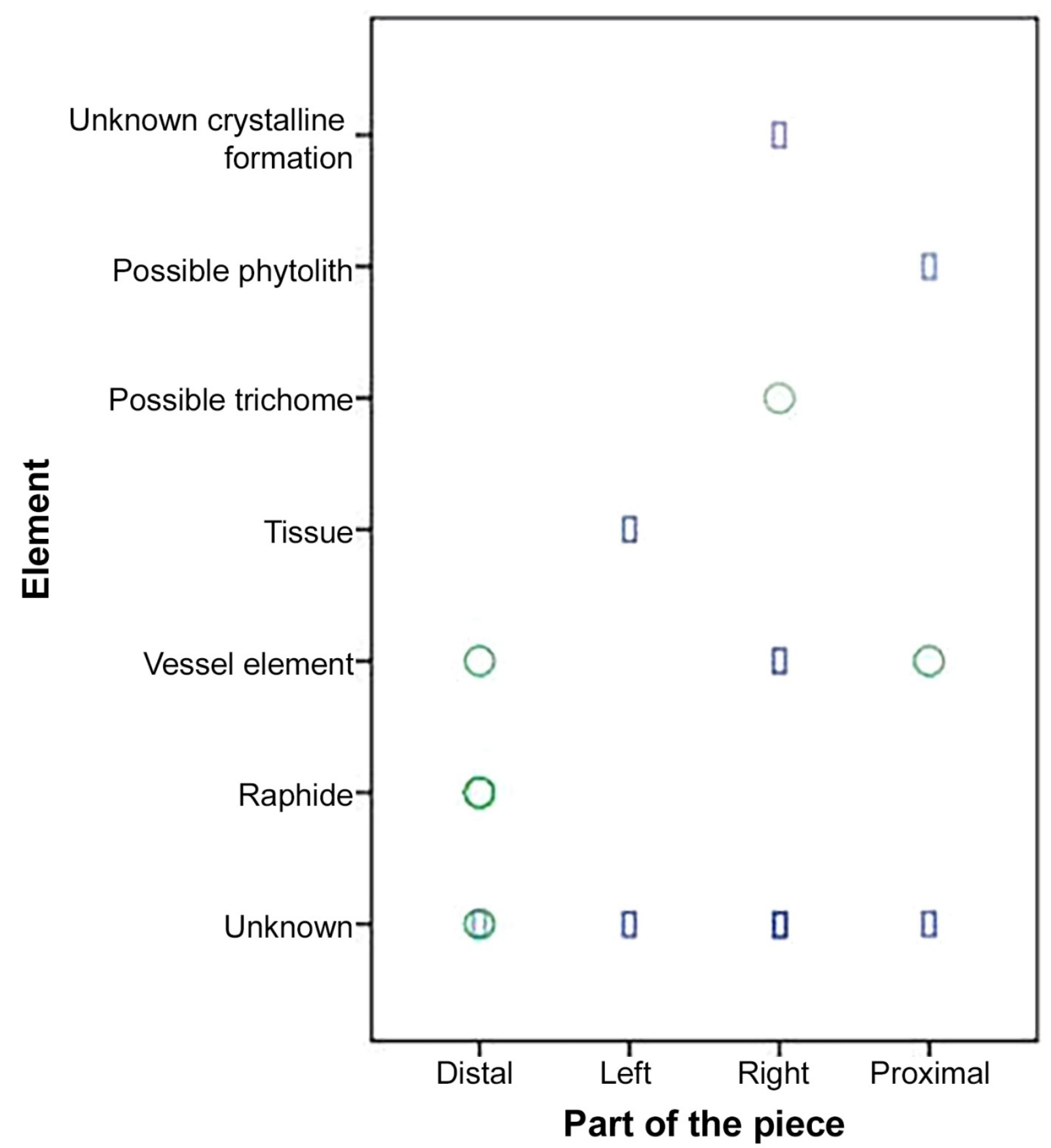

Figure 12. Other elements found in different parts of the tool. Elements recovered from sediment I are represented by blue rectangles, elements recovered from sediment II are represented by green circles. 

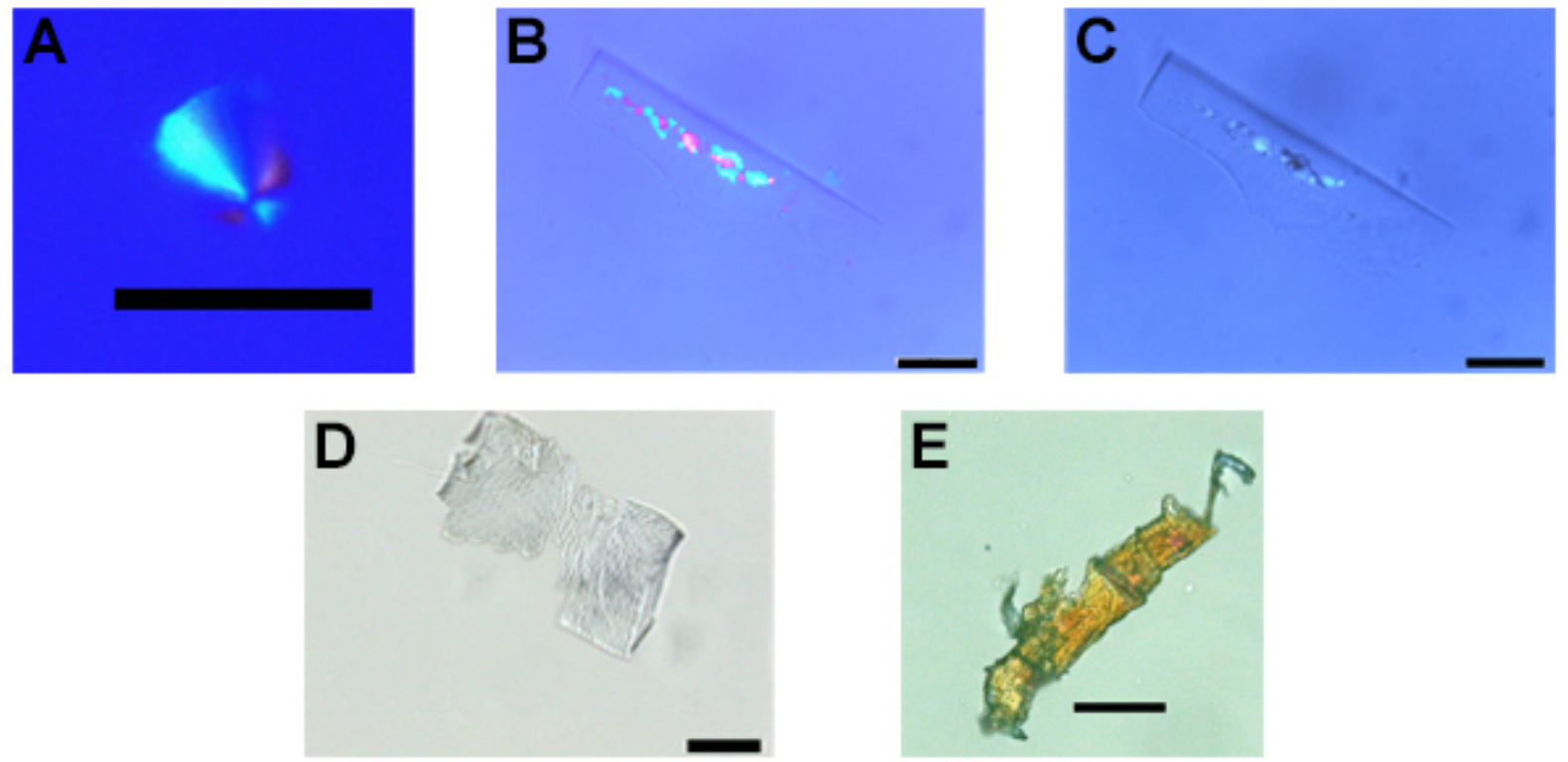

Figure 13. Elements found in sediment I (A-C) and sediment II (D-E) of the proximal area. A: Non-identified element. B-C: Possible phytolith. D-E: Vessel elements. Photos taken under bright field (C, D, E) and polarized (A, B) lights. Scale bar size: B-C, $20 \mu \mathrm{m}$; A, E, $50 \mu \mathrm{m}$; D, $100 \mu \mathrm{m}$. Photos by Rodrigo Angeles Flores.
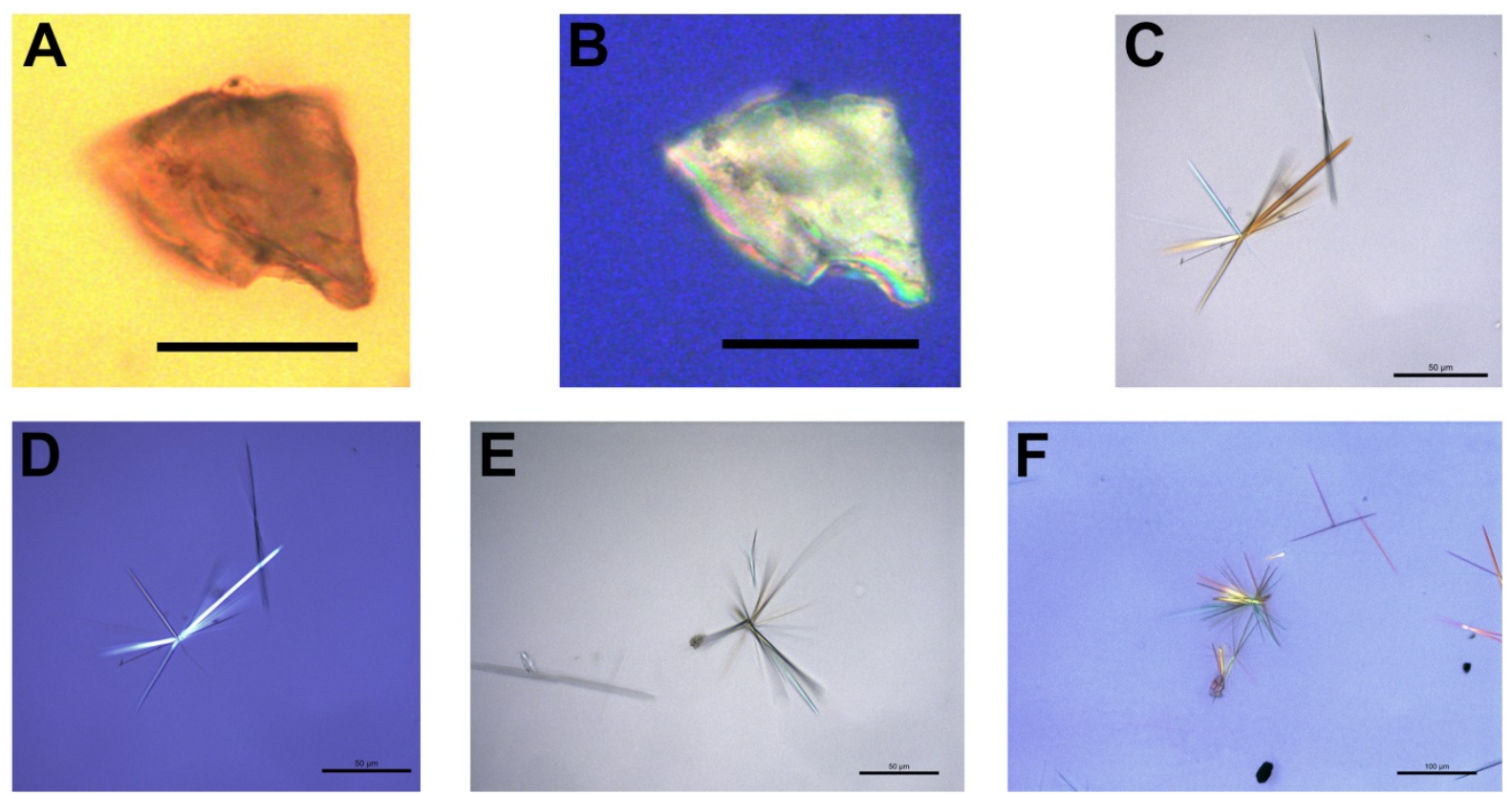

Figure 14. Various elements recovered from the sediment II of the distal part of the artifact. A-B: element 5. CF: Series of raphides; C-D: Series 1, E: Series 2, F: Series 3. Photos taken under bright field (A,C,E) and polarized light (B,F). Scale bars: A-E, $50 \mu \mathrm{m}$; F, $100 \mu \mathrm{m}$. Photos by Rodrigo Angeles Flores.

\subsection{Starch grains and other elements found in the control samples}

Some starch grains were found in the control air samples, nail polish and on one glass slide. Some of the starch grains were similar to those found in this study, but the diversity of types in the archaeological samples was much greater. 

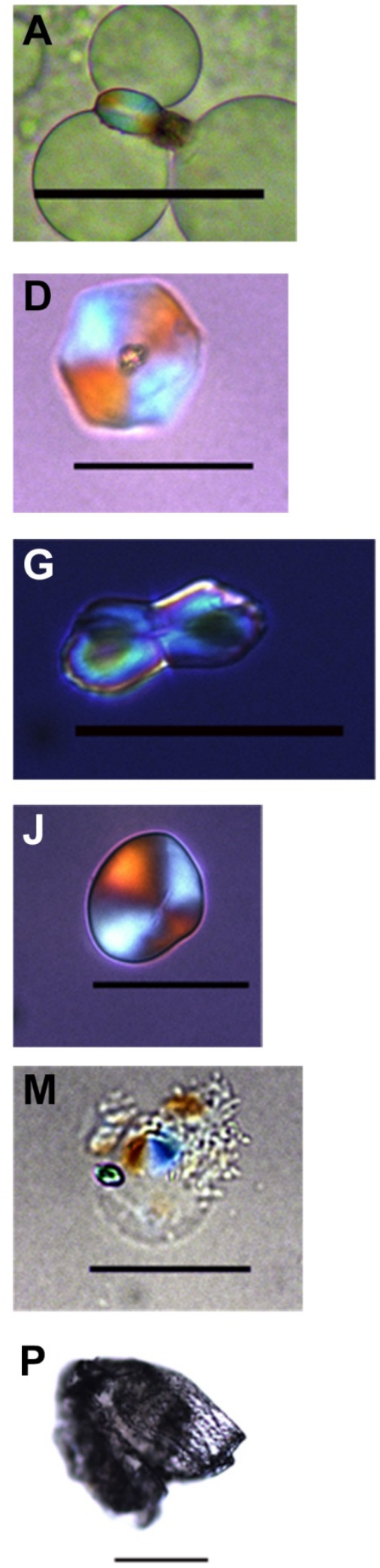

Figure 15. Starch grains and various elements recovered from sediment I (A, B and C) and II (D-R) at the distal part of the archaeological tool. AB: Starch grain 1 recovered from sediment I. C: Non-identified element 1 recovered from sediment I. D-L: Starch grains recovered from sediment II; D-E: grain 1; F-G: grains 2 and 3; HI: grain 4; J-L grain 5. M, N, Q, R: Non-identified elements recovered from sediment II; M: element 1, N: element 2; R: element 3. O-P: Vessel elements recovered from sediment II. Photos taken under bright field (A,

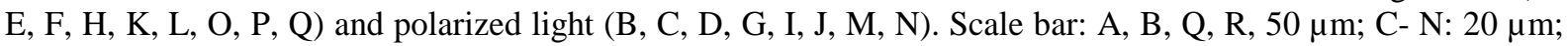
O-P, $100 \mu \mathrm{m}$. Photos by Rodrigo Angeles Flores. 

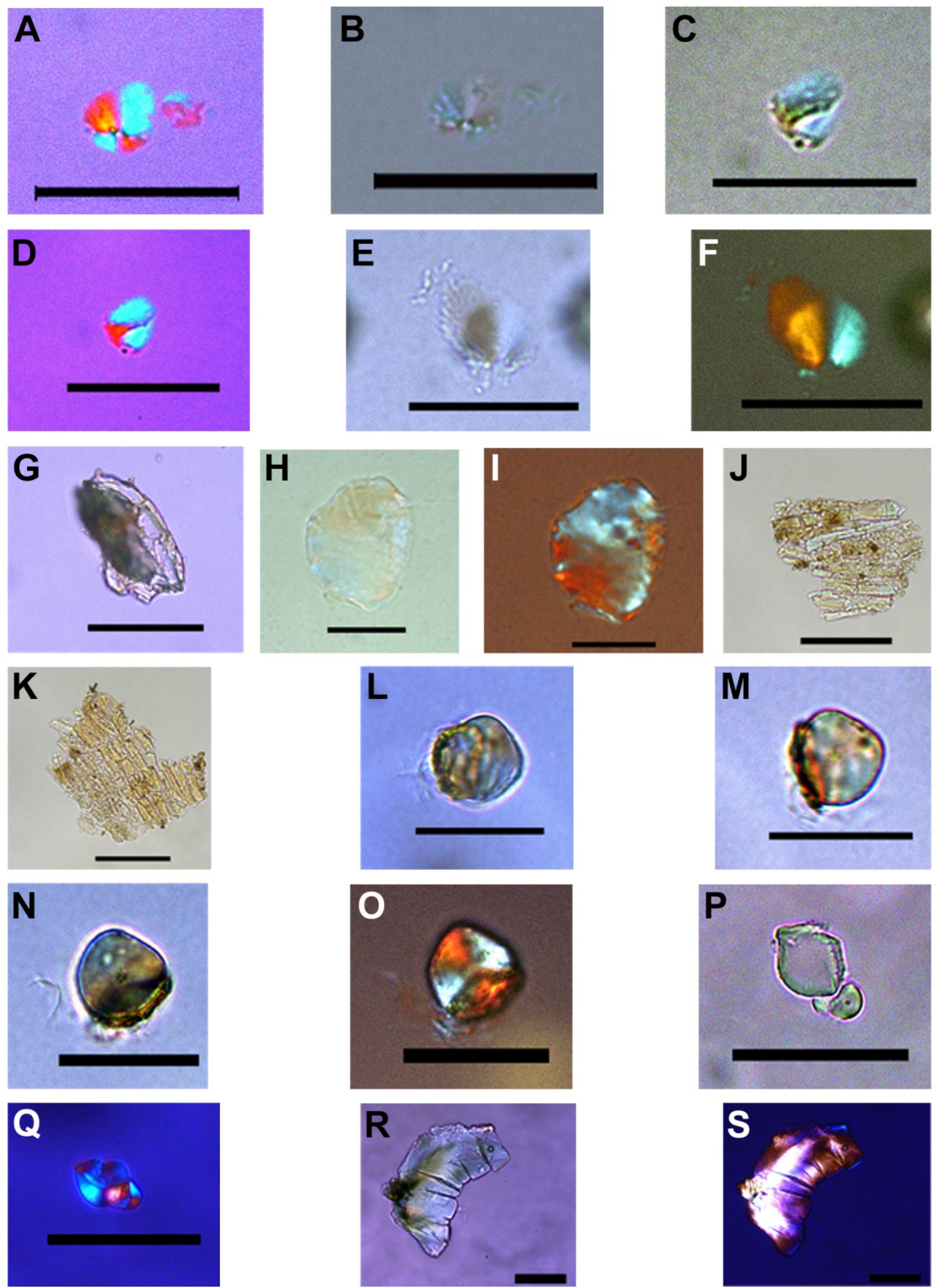

Figure 16. Starch grains and various elements recovered from sediment I (A-K) and sediment II (L-S) on the left side of the artifact. A-D: Non-identified elements recovered from sediment I; A-B: Non-identified element 1; CD: Non-identified element 2; E-F: Non-identified element 3; G: Non-identified element 4; H-I: Non identified element 5. J-K: Cellular tissue, possibly radial parenchyma. L-Q: Starch grains recovered from sediment II; L-O: Starch grain 1; P-Q: Starch grain 2. R-S: Non-identified element recovered from sediment II. Photos taken under bright field (B, C, E, G, H, J, K, L, M, N, P, R) and polarized (A, D, F, I, O, Q, S) light. Scale bar: A-F, H-I, L$\mathrm{O}, 20 \mu \mathrm{m} ; \mathrm{G}, \mathrm{J}-\mathrm{K}, \mathrm{P}-\mathrm{S}, 50 \mu \mathrm{m}$. Photos by Rodrigo Angeles Flores. 


\section{Discussion and conclusions}

It is not clear if the micro-remains found in sediment I (corresponding to the drybrushed) are related to the use of the artifact, with post-depositional sedimentation, or are a mixture of both. Nevertheless, we can be almost certain that the micro-remains for sediment II are related to the use of this tool.

It was not possible to reach an identification at the species level of the starch grains present in this study. However, due to the variability noted in the different kind of grains found, the use of this artifact to process a variety of starchy vegetables could be inferred. This is reinforced by the fact that starch grains were found in the active parts of the artifact, but not in the proximal part and is further supported by some of the elements found in the sediments of the tool, such as vessel elements or raphides, not found in the control samples, which are consistent with what one might find associated with starchy vegetables (for example, Hardy et al. 2001; Loy 2006; Crowther 2005; Horrocks et al. 2008).

The fact that some starch grains present some kind of modification such as partial gelatinization or a collapsed mesial part could be an indication of an early process of grinding and cooking starchy materials (see Babot 2003; Babot 2006; Henry et al. 2009). Still, more reference studies with starchy vegetables in the area are needed in order to achieve an identification of the taxa and the specific modification suffered by the starch grains.

As for the technological analysis, it was possible to identify some of the same technological features of the Itaparica tradition limaces (for examples, see Lourdeau 2010; Moreno de Sousa 2016). The limace is, obviously, older than typical Lagoa Santa lithic vestiges and presents no similarity with the subsequent Lagoa Santa industry. There is no evidence from other Lagoa Santa sites suggesting any kind of contact between the manufacturers of this limace and the groups responsible for the typical Lagoa Santa lithic industry. Technological analysis for Taquaraçu is still being carried out, but our preliminary results show that the lithic industry is extremely similar to the ones found at other Lagoa Santa sites, such as Lapa do Santo (Moreno de Souza 2014: 17) and Lapa das Boleiras (Pugliese 2007: 119). The same can be said if we take into consideration bone artifacts (spatulae, perforators) and the strong anthropogenic signal in the site matrix. In addition, we consider that the absence of other limaces in upper layers is enough to claim that the site is not related to the cultural unity known as Itaparica Tradition. The artifact's main features, such as general size, shape and raw material have been considered as not related to Lagoa Santa industry (Moreno de Sousa 2014: 57-58).

Starch grains and other elements found in the control samples make us think that some degree of modern contamination could be present. This indicates that the laboratory rooms were not completely starch free, but clearly this small contamination does not explain the presence of a very diverse assemblage of starch types and other plant elements that were confidently found in the archaeological samples (soil and limace edges). Detailed results and numbers can be consulted in Angeles Flores (2015).

The fact that micro-remains were recovered from an artifact that is older than 11,500 years old make this the earliest find of this type in the Americas until now; further work in similar contexts is needed in order to confirm this results. However, we can affirm that both the micro-remains found in the UTMs and the technological analysis seem to point to the function of this tool as a scraper that was used constantly to process diverse starchy vegetables.

Taking this into account, new questions emerge: Why was a limace at the bottom of the Lapa Grande de Taquaraçu site? Did this artifact come indirectly from this tradition and is it the product of a long-distance commercial network? Was this artifact used by the Itaparica 
people or by the Lagoa Santa people? Do the micro-remains found in the limace reflect a difference in the plants processed by the users of these industries?

In order to answer at least some of these questions, a compilation of the published studies of Lagoa Santa lithic industry is underway, including a complete systematic technological analysis of the few formal artifacts found in Lagoa Santa's industry, including lithic points and axe's blades. More arcaheobotanical studies are being carried out at the Evolutionary Human Studies (LEEH), including a vast base of reference samples that comprises macrobotanical and microbotanical remains, the latter focusing on starchy vegetables. Further micro-remain studies on lithic artifacts recovered in other locations of the Lagoa Santa region are planned to take place as masters and $\mathrm{PhD}$ projects in the forthcoming years. We are looking forward to this and we expect these studies to expand and refine our knowledge about the ancient habitants of this rich archaeological region.

\section{Acknowledgements}

We would like to thank all the people from the following laboratories: Plant Anatomy Lab., Plant Physiology Lab., Cell Biology Lab. and Laboratory for Human Evolutionary and Ecological Studies (LEEEH) from the Institute of Biosciences, University of São Paulo, Brazil for kindly allowing us to use their facilities, materials and advice, without which the present study would not have been possible. We would also like to thank Dr. Guillermo Acosta Ochoa from the Institute of Anthroplogical Research at the National Autonumus University of México (IIA-UNAM) who gave initial advice regarding starch analysis protocols for lithic artifacts. RAF was granted a scholarship by CNPq (Conselho Nacional de Desenvolvimento Científico e Tecnológico - "National Council of Technological and Scientific Development”, process: 160904/2011-0); CNPq also sponsored AGMA by means of an academic productivity fellowship (process: 300339/2008-9) and GC (process: 309805/2011-02). The excavation was also funded by FAPESP (Fundação de Amparo à Pesquisa do Estado de São Paulo - "São Paulo Research Foundation”, tematic project, process 99/00670-7) under the coordination of Professor Walter Alves Neves, to whom we owe the opportunity of building our data.

\section{References}

Angeles Flores R. 2015, Uso de recursos vegetais em Lapa Grande de Taquraçu: Evidências macro e microscópicas. Master thesis at Museu de Arqueologia e Etnologia, Universidade de São Paulo, São Paulo, 308 p. (in Portuguese) (“Use of vegetal resources at Lapa Grande de Taquaraçu: Macro and Microscopic evidences”) doi:10.11606/d.71.2015.tde-30072015-144906

Araujo, A.G.M., Neves, W.A., Pilo, L.B. \& Atui, J.P.V. 2005, Holocene dryness and human occupation in Brazil during the “Archaic Gap”. Quaternary Research, 64(3): 298-307. doi:10.1016/j.yqres.2005.08.002

Araujo, A.G.M., Feathers, J.K., Arroyo-Kalin, M. \& Tizuka, M.M. 2008, Lapa das Boleiras rockshelter: Stratigraphy and formation processes at a Paleoamerican site in Central Brazil. Journal of Archaeological Science, 35(2): 3186-3202. doi:10.1016/j.jas.2008.07.007

Araujo, A.G.M., Neves, W. \& Kipnis, R. 2012, Lagoa Santa Revisited: An Overview of the Chronology, Subsistence, and Material Culture of Paleoindian Sites in Eastern Central Brazil. Latin American Antiquity, 23(4): 533-550. doi:10.7183/1045-6635.23.4.533 
Araujo, A.G.M. \& Pugliese Jr., F. 2009, The use of non-flint raw materials by Paleoindians in eastern South America: A Brazilian perspective. In: Non-Flint Raw Material Use in Prehistory: Old prejudices and new directions (Sternke, F., Eigeland, L. \& Costa, L.J., Eds.), BAR International Series Vol. 1939, Archaeopress, Oxford: p. 169-175.

Araujo, A.G.M. \& Oliveira, E.C. 2010, A Lapa das Boleiras: Inserção ambiental, histórico das pesquisas e caraterização do sítio. In: Lapa das Boleiras, Um Sítio Paleoíndio do Carste de Lagoa Santa, MG, Brasil (Araujo, A.G.M. \& Neves, W.A., Eds.), Annablume, São Paulo: p. 14-23. (in Portuguese) ("Lapa das Boleiras: Environmental insertion, history or research and characterization of the site”. In: "Lapa das Boleiras. A Paleoindian site from the Karst of Lagoa Santa")

Araujo, A.G.M. \& Pugliese, F.A. 2010, A indústria Lítica. In: Lapa das Boleiras, Um Sítio Paleoíndio do Carste de Lagoa Santa, MG, Brasil (Araujo, A.G.M. \& Neves, W.A., Eds.), Annablume, São Paulo: p. 79-109. (in Portuguese) (“The lithic industry”. In: "Lapa das Boleiras. A Paleoindian site from the Karst of Lagoa Santa”)

Babot, M.P. 2003, Starch grain damage as an indicator of food processing. In: Phytolith and starch research in the Australian-Pacific Asian regions: The state of the art (Hart, D.M. \& Wallis, L.A., Eds.), Pandanus Books, Canberra: p. 69-81.

Babot, M.P. 2006, Damage on Starch from Processing Andean Food Plants (Box 4.4). In: Ancient Starch Research (Torrence, R. \& Barton, H., Eds.), Left Coast Press, Walnut Creek: p. 66-67.

Bernardo, D.V. 2007, Afinidades morfológicas intra e extra-continentais dos Paleoíndios de Lagoa Santa: Uma nova abordagem. Master thesis at Instituto de Biociências, Universidade de São Paulo, São Paulo, 333 p. (in Portuguese) ("Intra and extracontinental morphological affinities of Lagoa Santa Paleoindians: A new approach”) doi:10.11606/d.41.2007.tde-21122007-140301

Boëda, E. 1997, Technogenèse de Systèmes de Production Lithique au Paléolithique Inférieur et Moyen e Europe Occidentale et au Proche-Orient. Ph.D. dissertation at Université de Paris X Nanterre, Paris, 173 p. (in French) ("Technogenesis of Lithic Produciton Systems at Lower and Medium Paleolithic in Western Europe and in Near East”)

Calderón, V. 1973. A Pesquisa Arqueológica Nos Estados da Bahia e Rio Grande do Norte. Dédalo, 9(17-18): 25-32. (in Portuguese) ("The archaeological research in Bahia and Rio Grande do Norte states”)

Cascon, L.M. 2009, Pequenas grandes permanências: Métodos e técnicas para a construção de coleções de referencia e extração de grãos de amido e outros microvestígios de diversos contextos. Specialization thesis at Museu Nacional, Universidade Federal do Rio de Janeiro, Rio de Janeiro, 78 p. (in Portuguese) ("Small large permanences: Methods and techniques for the construction of reference collections and extraction of starch granules and other micro-remains from diverse contexts").

Cascon, L.M. 2010, Alimentação na floresta tropical: Um estudo de caso no sítio Hatahara, Amazônia Central, com base em microvestígios botânicos. Master thesis at Museu Nacional, Universidade Federal do Rio de Janeiro, Rio de Janeiro, 195 p. (in Portuguese) ("Nourishment in the rainforest: A case study on the site Hatahara, Central Amazon, based on botanical micro-remains")

Crowther, A. 2005, Starch Residues on Undecorated Lapita Pottery from Anir, New Ireland. Archaeology in Oceania, 40(2): 62-66. doi:10.1002/j.1834-4453.2005.tb00586.x 
Crowther, A., Haslam, M., Oakden, N., Walde, D. \& Mercader, J. 2014, Documenting contamination in ancient starch laboratories. Journal of Archaeological Science, 49: 90104. doi:10.1016/j.jas.2014.04.023

Danzeglocke, U., Jöris, O. \& Weninger, B. 2007, CalPal Online (Version 1.5). University of Cologne, Germanay. Retrieved August 2015. URL: http://www.calpal-online.de/

Dauvois, M. 1976, Precis de Dessin Dynamique et Structural des Industries Lithiques Préhistoriques. Fanlac, Périgueux, 263 p. (in French) ("Dynamic and Structural Drawing precise of Prehistoric Lithic Industries”).

Fogaça, E. 2003. Instrumentos líticos unifaciais da transição Pleistoceno-Holoceno no Planalto Central do Brasil: Individualidade e especificidade dos objetos técnicos. Canindé, 3: 9-35. (in Portuguese) ("Unifacial lithic tools from Pleistocene-Holocene Transition in Brazil Central Plateau: Technic objects individuality and specifity”)

Gardiman, G.G. 2014, Vereda III: Uma análise paleoetnobotânica. Bachelor thesis at Faculdade de Filosofia e Ciências Humanas, Universidade Federal de Minas Gerais, Belo Horizonte, 141 p. (in Portuguese) ("Vereda III: A paleoethnobotanic analysis”)

Hardy, B.L., Kay, M., Marks, A.E. \& Monigal, K. 2001, Stone tool function at the Paleolithic sites of Starosele and Buran Kaya III, Crimea: Behavioral implications. Proceedings of the National Academy of Sciences of the United States of America, 98(19): 1097210977. doi:10.1073/pnas.191384498

Henry, A.G., Hudson, H.F. \& Piperno, D.R. 2009, Changes in starch grain morphologies from cooking. Journal of Archaeological Science, 36(3): 915-922. doi:10.1016/j.jas.2008.11.008

Horrocks, M., Grant-Mackie, J. \& Matisoo-Smith, E. 2008, Introduced taro (Colocasia esculenta) and yams (Dioscorea spp.) in Podtanean (2700-1800years BP) deposits from Mé Auré Cave (WMD007), Moindou, New Caledonia. Journal of Archaeological Science, 35(1): 169-180. doi:10.1016/j.jas.2007.03.001

Hurt, W.R., \& Blasi, O. 1969, O Projeto Arqueológico “Lagoa Santa” - Minas Gerais, Brasil. Arquivos do Museu Paranaense, Nova Série, (4): 60. (in Portuguese) ("The "Lagoa Santa” archaeological project - Minas Gerais, Brazil”)

Inizan, M..L., Reduron-Ballinger, M., Roche, H., \& Tixier, J. 1995, Technologie de la Pierre Taillé. Centre de Recherche et d'Etudes Politiques (CREP), Paris, 122 p. (in French) ("Flaked stone technology")

Lamming-Emperaire, A., Prous, A., Moraes A. V., \& Beltrao, M. (Eds.). 1975, Grottes et abris de la region de Lagoa Santa, premier rapport de la Mission Archéologique Franco-Brésilienne de Lagoa Santa, Cahiers d'Archéologie de Amerique do Sud Vol 1. Ecole Pratique des Hautes Études, Paris, 185 p. (in French) ("Caves and Shelters of the region of Lagoa Santa, first report of the French-Brazilian Archaeological Mission of Lagoa Santa”)

Laurence, A.R., Thoms, A.V., Bryant, V.M. \& McDonough, C. 2011, Airborne Starch Granules as a Potential Contamination Source at Archaeological Sites. Journal of Ethnobiology, 31(2): 213-232. doi:10.2993/0278-0771-31.2.213

Leroi-Gourhan, A. 1965, Le Geste et le Parole, tome 2. La Mémoire et les Rhythmes. Albin Michel, Paris, 288 p. (in French) (“Gesture and word, volume 2. Memory and rhythms”) 
Lourdeau, A. 2010, Le technocomplexe Itaparica. Définition techno-fonctionelle des industries à pièces façonnées unifacialement à une face plane dans le Centre et le NordEst du Brésil pendant la transition Pléistocène-Holocène et l'Holocène Ancien. Ph.D. dissertation at Université Paris Ouest Nanterre La Defense, Paris, 477 p. (in French) ("The Itaparica technocomplex. Technofunctional definition of the one opposite plan face unifacial reduction pieces in Center and Northeastern Brazil during PleistoceneHolocene transition and Early Holocene”)

Loy, T. 2006, Raphides (Box 7.7). In: Ancient starch research (Torrence. R. \& Barton, H. Eds), Left Coast Press, Walnut Creek: p. 136.

Malainey, M.E. 2011, Blood and protein residue analysis. In: A consumer's guide to archaeological science, analytical techniques (Malainey, M.E.), Springer, New York: p. 219-236. doi:10.1007/978-1-4419-5704-7_15

Matheson, C.D., Hall, J. \& Viel, R. 2009, Drawing first blood from Maya ceramics at Copán, Honduras. In: Archaeological science under a microscope, studies in residue and ancient DNA analysis in Honour of Thomas H. Loy (Haslam, M., Robertson, G., Crowther, A., Nugent, S. \& Kirkwood, L., Eds.), The Australian National University Press, Canberra: p. 190-197.

Mauss, M. 1936, Les techniques du corps. Journal de Psychologie, 32(3-4). 271-293. (in French) ("The techniques of the body").

Melo Jr, J.C.F. \& Ceccantini, G. 2010, Análise antracológico preliminar. In: Lapa das Boleiras, Um Sítio Paleoíndio do Carste de Lagoa Santa, MG, Brasil (Araujo, A.G.M. \& Neves, W.A., Eds.), Annablume, São Paulo: p. 149-161. (in Portuguese) ("Preliminary anthracological analysis” In: “Lapa das Boleiras. A Paleoindian site from the Karst of Lagoa Santa”)

Miller, E. T. 1987. Pesquisas arqueológicas paleoindígenas no Brasil ocidental. Estudios Atacameños, 8: 39-64. (in Portuguese) ("Paleoindigenous archaeological research in western Brazil”)

Moreno de Sousa, J. C. 2014, Cognição e cultura no mundo material: Os Itaparicas, os Umbus e os "Lagoassantenses". Volume 1. Master thesis at Museu de Arqueologia e Etnologia, Universidade de São Paulo, São Paulo, 200 p. (in Portuguese) (“Cognition and culture in the material world: The Itaparicas, the Umbus and The "Lagoassantenses”. Volume 1.”) doi:10.11606/d.71.2014.tde-26092014-160812

Moreno de Sousa, J.C. 2016, Lithic Technology of an Itaparica Industry Archaeological Site: The Gruta Das Araras Rockshelter , Midwest Brazil. Journal of Lithic Studies, 3(1): 20 p. doi:10.2218/jls.v3i1.1298

Nakamura, C., Melo Junior, J.C.F. \& Ceccantini, G. 2010, Macro-restos vegetais: Uma abordagem paleoetnobotânica e paleoambiental. In: Lapa das Boleiras, um sítio Paleoíndio do Carste de Lagoa Santa, MG, Brasil (Araujo, A.G.M. \& Neves, W.A., Eds.), Annablume, São Paulo: p. 164-190. (in Portuguese) ("Vegetable macro-remains: A paleoethnobotanic and paleoenvironmental approach”)

Neves, W.A., Araujo, A.G.M., Bernardo, D.V., Kipnis, R. \& Feathers, J.K. 2012, Rock art at the pleistocene/holocene boundary in Eastern South America. PloS one, 7(2): 1-16. doi:10.1371/journal.pone.0032228 
Neves, W.A. \& Hubbe, M. 2005, Cranial morphology of early Americans from Lagoa Santa, Brazil: implications for the settlement of the New World. Proceedings of the National Academy of Sciences of the United States of America, 102(51): 18309-18314. doi:10.1073/pnas.0507185102

Neves, W.A, Hubbe, M. \& Piló, L.B. 2007, Early Holocene human skeletal remains from Sumidouro Cave, Lagoa Santa, Brazil: History of discoveries, geological and chronological context, and comparative cranial morphology. Journal of Human Evolution, 52(1): 16-30. doi:10.1016/j.jhevol.2006.07.012

Neves, W.A, Prous, A., González-José, R., Kipnis, R. \& Powell, J. 2003, Early Holocene human skeletal remains from Santana do Riacho, Brazil: Implications for the settlement of the New World. Journal of Human Evolution, 45(1): 19-42. doi:10.1016/s00472484(03)00081-2

Neves, W.A, \& Pucciarelli, H.M. 1991, Morphological affinities of the first Americans: An exploratory analysis based on early South American human remains. Journal of Human Evolution, 21(4): 261-273. doi:10.1016/0047-2484(91)90107-7

Neves, W. A., Prous, A., González-José, R., Kipnis, R., \& Powell, J. 2004, Early Holocene human skeletal remains from Cerca Grande, Lagoa Santa, Central Brazil, and the origins of the first Americans. World Archaeology, 36(4): 479-501. doi:10.1080/0043824042000303665

Okumura, M. M. M., \& Araujo, A. G. M. 2013, Pontas bifaciais no Brasil Meridional: Caracterização estatística das formas e suas implicações culturais. Revista do Museu de Arqueologia e Etnologia, (23): 111-127. (in Portuguese) ("Bifacial points in Meridional Brazil: Statistical characterization of the forms and its cultural implications”)

Okumura, M.M.M. \& Araujo, A.G.M. 2014, Long-term cultural stability in hunter-gatherers: A case study using traditional and geometric morphometric analysis of lithic stemmed bifacial points from Southern Brazil. Journal of Archaeological Science, 45: 59-71. doi:10.1016/j.jas.2014.02.009

Pagán- Jiménez, J.R. \& Oliver, J.R. 2008, Starch residues on lithic artifacts from two contrasting contexts in northwestern Puerto Rico: Los Muertos Cave and Vega de Nelo Vargas farmstead. In: Crossing the Borders: New methods and techniques in the study of archaeological materials from the Caribbean (Hofman, C.L., Hoogland, M.L.P. \& van Gin, A.L., Eds.), The University of Alabama Press, Tuscaloosa: p. 137-158.

Pagán-Jiménez, J.R. 2011, Useful plants identified through ancient starch grains recovered from ceramic and lithic artefacts, the Chemin Saint -Louis site, French Guiana. (Operational report of the archaeological excavation) Chemin Saint-Louis, Annexes, Volume 2. Unpublished report for the Institut National de Recherches Archéologiques Préventives (INRAP), Bégles, France: p. 399-469.

Prous, A. 1997, Archéologie du cours moyen du Rio São Francisco (vallés des rios Peruaçu et Cochá). Arquivos do Museu de História Natural da UFMG, 17-18: 19-67. (in French) ("Archaeology of the Middle São Francisco River (Peruaçu and Cocha Rivers' Valleys”) 
Pugliese, F.A. 2007. Os líticos de Lagoa Santa: Um estudo sobre organização tecnológica de caçadores-coletores do Brasil central. Master thesis at Museu de Arqueologia e Etnologia, Universidade de São Paulo, São Paulo, 154 p. (in Portuguese) ("The Lagoa Santa lithics: A study about the technological organization of hunter-gatherers from central Brazil”) doi:10.11606/d.71.2008.tde-10042008-110501

Rasband, W.S. (1997), ImageJ (Version 1.50i). U.S. National Institutes of Health, Bethesda, Maryland, USA. URL: http://imagej.nih.gov/ij/

Resende, E.T., \& Prous, A. 1991, Os vestígios vegetais do Grande Abrigo de Santana do Riacho. Arquivos do Museu de História Natural da Universidade Federal de Minas Gerais, 12: 87-111. (in Portuguese) ("The vegetal remains of Grande Abrigo de Santana do Riacho" in "Arquives from the Museum of Natural History of Universidade Federal de Minas Gerais”).

Rodrigues Silva, D. G. 2006, Estratégias de Subsistência de Sociedades Forrageiras PréHistóricas Da Região de Lagoa Santa, MG: Uma Abordagem Paleoetnobotânica. undefended Master thesis at Instituto de Biociências, Universidade de São Paulo, São Paulo, 129 p. (in Portuguese) (Livelihood strategies from prehistoric forager societies of the Lagoa Santa Region, MG: An paleoethnobotanic approach)

Schmitz, P. I., Barbosa, A. S., Jacobus, A. L., \& Ribeiro, M. B. 1989. Arqueologia nos Cerrados do Brasil Central: Serranópolis I. Pesquisas - Antropologia, 44: 1-208. (in Portuguese) (“Archaeology in Brazil Central cerrados: Serranópolis I”)

Seguchi, N., McKeown, A., Schmidt, R., Umeda, H., \& Brace, C.L. 2011, An Alternative View of the Peopling of South America: Lagoa Santa in Craniometric Perspective. Anthropological Science, 119(1): 21-38. doi:10.1537/ase.090921

Tudela, D.R. 2013. Caracterização Físico-Química de Sedimentos do Sítio Arqueológico Lapa Grande de Taquaraçu, MG. Master thesis at Instituto de Pesquisas Nucleares, Universidade de São Paulo, 96 p. (in Portuguese) ("Physico-chemical characterization of sediments from Lapa Grande de Taquaraçu, MG”) doi:10.11606/d.85.2013.tde23092013-131738

Williamson, B.S. 2000, Direct testing of rock painting pigments for traces of haemoglobin at Rose Cottage Cave, South Africa. Journal of archaeological science, 27(9): 755-762. doi:10.1006/jasc.1999.0489 